\title{
Heteroatom-Doped Metal-Free Carbon Nanomaterials as Potential Electrocatalysts
}

\author{
Jayeeta Chattopadhyay ${ }^{1, *}$, Tara Sankar Pathak ${ }^{2}$ and Daewon Pak ${ }^{3, *}$ \\ 1 Chemistry Department, Amity University Jharkhand, Ranchi 834002, India \\ 2 Department of Science and Humanities, Surendra Institute of Engineering and Management, Siliguri, \\ Darjeeling 734009, India; drtspathak1971@gmail.com \\ 3 Department of Environmental Engineering, Seoul National University of Science and Technology, \\ Gongneung-ro, Nowon-gu, Seoul 01811, Korea \\ * Correspondence: jchattopadhyay@rnc.amity.edu (J.C.); daewon@seoultech.ac.kr (D.P.); \\ Tel.: +91-9748441723 (J.C.)
}

check for updates

Citation: Chattopadhyay, J.; Pathak T.S.; Pak, D. Heteroatom-Doped Metal-Free Carbon Nanomaterials as Potential Electrocatalysts. Molecules 2022, 27, 670. https://doi.org/ $10.3390 /$ molecules 27030670

Academic Editors: Sung-Hoon Kim and Wan Soo Yun

Received: 2 January 2022

Accepted: 18 January 2022

Published: 20 January 2022

Publisher's Note: MDPI stays neutral with regard to jurisdictional claims in published maps and institutional affiliations.

Copyright: (C) 2022 by the authors. Licensee MDPI, Basel, Switzerland. This article is an open access article distributed under the terms and conditions of the Creative Commons Attribution (CC BY) license (https:// creativecommons.org/licenses/by/ $4.0 /)$.

\begin{abstract}
In recent years, heteroatom-incorporated specially structured metal-free carbon nanomaterials have drawn huge attention among researchers. In comparison to the undoped carbon nanomaterials, heteroatoms such as nitrogen-, sulphur-, boron-, phosphorous-, etc., incorporated nanomaterials have become well-accepted as potential electrocatalysts in water splitting, supercapacitors and dye-sensitized solar cells. This review puts special emphasis on the most popular synthetic strategies of heteroatom-doped and co-doped metal-free carbon nanomaterials, viz., chemical vapor deposition, pyrolysis, solvothermal process, etc., utilized in last two decades. These specially structured nanomaterials' extensive applications as potential electrocatalysts are taken into consideration in this article. Their comparative enhancement of electrocatalytic performance with incorporation of heteroatoms has also been discussed.
\end{abstract}

Keywords: carbon nanomaterials; nitrogen doping; sulphur doping; co-doping; electrocatalysts

\section{Introduction}

Energy demand and energy production are continuously establishing a disproportional relation to each other, which leads to a crucial environmental crisis globally. The over consumption of fossil fuels and excessive $\mathrm{CO}_{2}$ emission results in global warming, and consequently, the scientific community is being faced with the most challenging situation in mitigating this serious environmental crisis [1-3]. Moving towards this aim, fuel cells, metal-air batteries, water electrolysers, rechargeable batteries and electrochemical capacitors constitute various technologies in respect to energy production/storage [4]. In recent years, these applications are mainly covered with various research works on oxygen reduction reaction (ORR), oxygen evolution reaction (OER), hydrogen evolution reaction (HER) and electro-reduction reaction of carbon dioxide $\left(\mathrm{CO}_{2} \mathrm{RR}\right)$ [5-8]. However, these electrochemical processes are largely restricted due to their high activation energy barriers, especially in oxygen reduction reaction (ORR) kinetics performed at the cathode $[9,10]$. The much slower cathodic ORR limits the overall output performance of these useful technologies [11]. Usually, electrocatalysts play a pivotal role in reducing the activation energy barriers of ORR process. In last two decades, platinum $(\mathrm{Pt})$-based materials are continuously considered the most potential electrocatalysts in this regard, leading to relatively higher current density and lower overpotential value [12-15]. However, largescale application of these materials was restricted due to their cost ineffectiveness, easy dissolution of $\mathrm{Pt}$, instability due to $\mathrm{CO}$ deactivation and fuel crossover effect. For these reasons, today, researchers are more inclined to develop electrocatalysts with the following priorities: minimization of the $\mathrm{Pt}$ metal loading; alloying of $\mathrm{Pt}$ with other transition 
metals to improve catalytic performance (Pt-Co, Pt-Ni, Pt-Fe, Pt-Ru, Pt-Pd, Pt-Rh, Pt$\mathrm{TiO}_{2}$ and Pt-Sn catalysts) [16-18]; advanced nonprecious metals and metal oxides [19-23]; metal-incorporated carbon materials [24-27]; and even metal-free catalysts [28-30] with remarkable electrocatalytic performance, enhanced durability and greater electrochemical stability with satisfying cost-effectiveness. The nonprecious metal-based catalysts always show lower catalytic activity in comparison to $\mathrm{Pt} / \mathrm{C}$, and they also show poor durability due to metal leaching during application. In contrast, the metal-free carbon-based materials perform excellent catalytic activity during ORR [31-35]. Moreover, they are extraordinarily chemically stabile, cost-effective, and environmentally friendly. These remarkable properties make various carbon nanostructures, viz., graphene, carbon nanotubes (CNTs) and carbon nanohorns (CNHs), hugely popular in many potential applications. The family of carbon allotropes is mainly constituted of a huge $\mathrm{sp}^{2}$ lattice, which is an extended $\pi$ conjugation system, resulting in greater thermal and electrical conductivity. Moreover, these specially structured materials act as a substrate in various covalent and noncovalent modifications on their lattice structure, which results in the improvement of their inherent characteristics and adoption of new ones [36-39].

The carbon nanomaterials can be functionalized with the alteration of their surface, interfacial structure and electronic properties, extending their applicability to higher levels. One of the most cutting-edge functionalization technologies is chemical doping, when carbon lattice is enriched with heteroatoms. They can be incorporated in the adsorptive form (in the case of metal atoms), which leaves the $\mathrm{sp}^{2}$ lattice intact. However, heteroatoms of similar radius to $\mathrm{C}$, e.g., N, O, P, S, B, etc., are used to bind different configurations, where substantial effect can be seen through $\mathrm{sp}^{3}$ defects. Incorporation of heteroatoms, which are more electronegative than $\mathrm{C}$, can polarize the $\mathrm{sp}^{2}$ network accordingly, therefore resulting into novel electrochemical properties. In last two decades, introduction of heteroatoms into the graphitic framework structures garnered great attention from researchers. Boron, nitrogen, phosphorus, sulphur, fluorine, chlorine, bromine, iodine, selenium, antimony and tellurium have widely been used as heteroatoms [40-49]. Several reviews have been published in last few years on heteroatom-doped nanomaterials applied suitably in ORR; however, very few scientists have covered their overall applicability in other electrochemical reactions. This review covers heteroatom doping on metal-free carbon nanomaterials as a potential electrocatalyst, discussing the future challenges and perspectives in this rapidly evolving field. In this work, special attention is also paid to their synthetic strategies and how their structural orientation could affect their applications as electrocatalysts. Scheme 1 represented the various types of elecctrocatalytic applications of hetero-atom doped metalfree nano-materials. This article is not restricted to discussing their applications in oxygen reduction reaction only; we also investigate their applications in all types of electrochemical processes. This review work also provides a brief overview of the gradual research progress of these materials in last two decades and the challenges confronted in potential applications of them as metal-free electrocatalysts. Figure $1 \mathrm{a}, \mathrm{b}$ and Table 1 described the developments of heteroatoms incorporated metal-free carbon nanomaterials and their potential applications in different electrocatalytic activities in last two decades. 

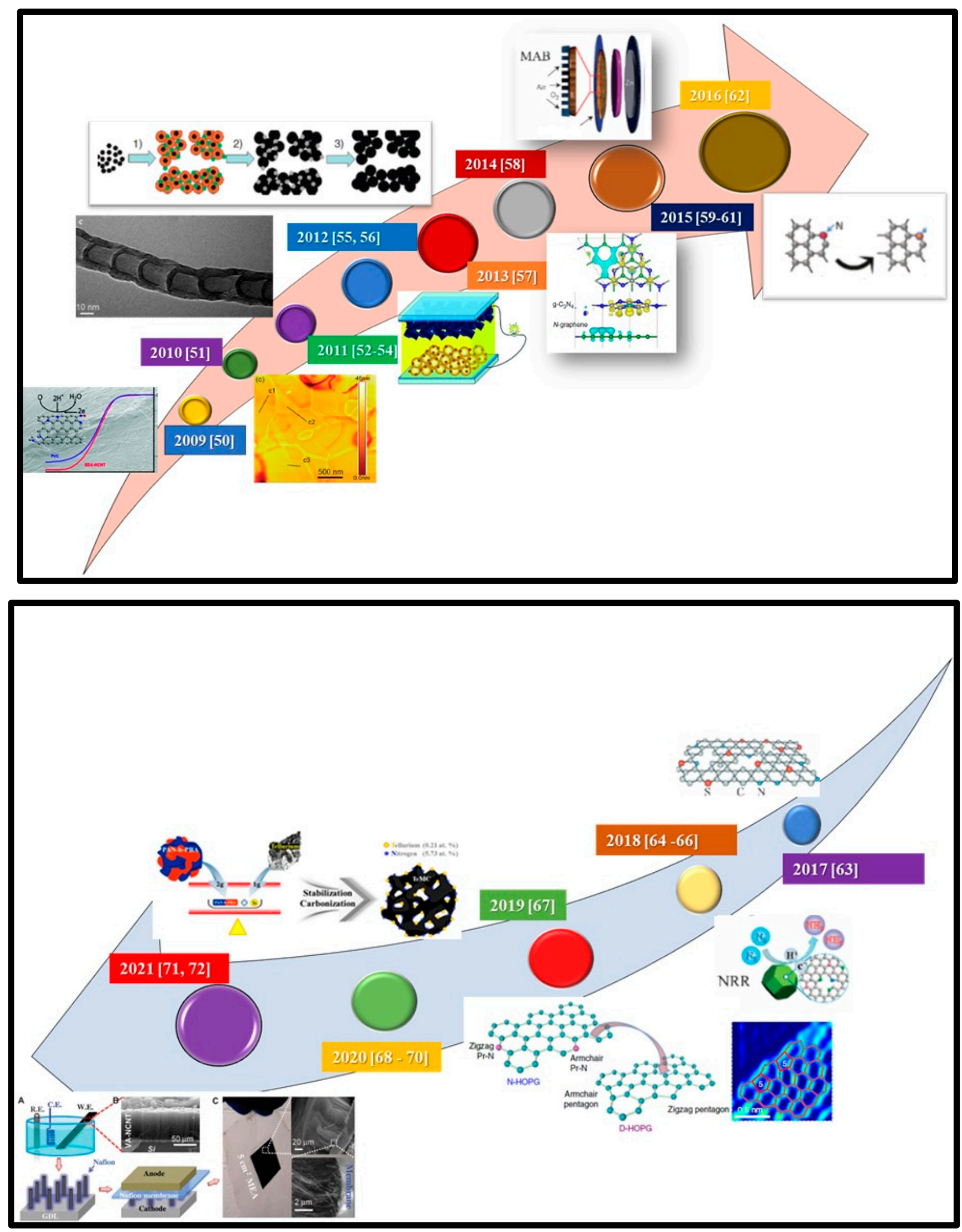

Figure 1. (a) [50-62] and (b) [63-72]: Developments of heteroatoms incorporated metal-free carbon nanomaterials in last two decades. 


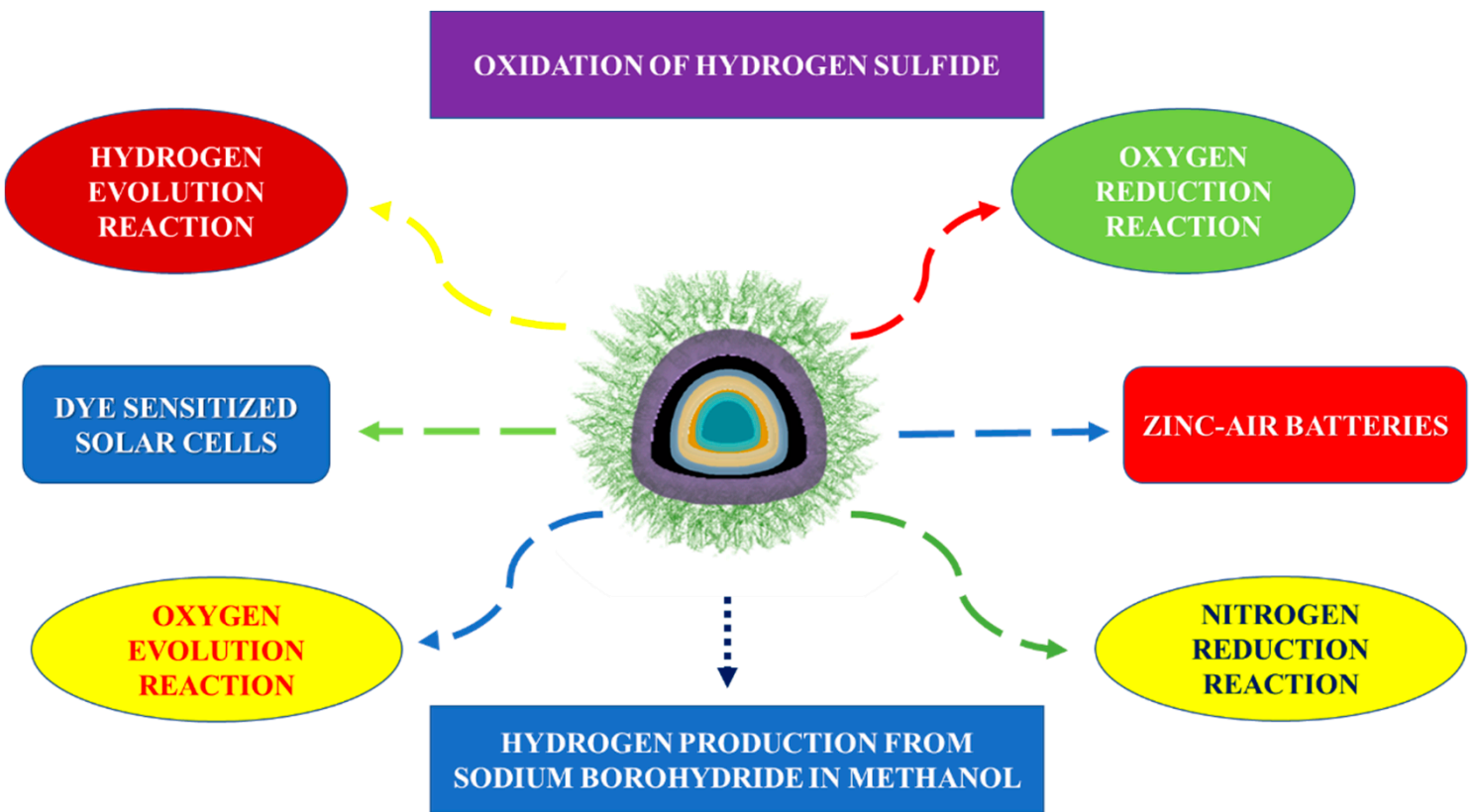

Scheme 1. Schematic representation of hetero-atom doped metal-free electrocatalysts in different potential application fields.

Table 1. Heteroatom-incorporated metal-free carbon nanomaterials, synthesis and application in last two decades.

\begin{tabular}{|c|c|c|c|}
\hline Year & Materials & Synthesis Method & Application \\
\hline 2009 & N-doped carbon nanotubes & Chemical vapor deposition method & ORR in fuel cell application [50] \\
\hline 2010 & N-doped graphene & Chemical vapor deposition method & ORR in fuel cell application [51] \\
\hline 2011 & N-doped carbon nanotubes & $\begin{array}{l}\text { Chemical vapor deposition method [52], } \\
\text { Amine Flames [53], Chemical vapor } \\
\text { deposition method [54] }\end{array}$ & $\begin{array}{l}\text { ORR in microbial fuel cells [52], } \\
\text { Supercapacitors [53] }\end{array}$ \\
\hline 2012 & $\begin{array}{l}\text { (i) N-doped graphene foam, } \\
\text { (ii) N-doped graphene quantum dots }\end{array}$ & $\begin{array}{l}\text { (i) Postsynthesis annealing in ammonia } \\
\text { (ii) Solution Chemistry }\end{array}$ & (i) Dye-sensitized solar cells [55], (ii) ORR [56] \\
\hline 2013 & N-doped carbon nanomaterials & Solvothermal process & Water oxidation [57] \\
\hline 2014 & $\mathrm{C}_{3} \mathrm{~N}_{4} @ \mathrm{NG}$ & Chemical vapor deposition method & HER electrocatalysts [58] \\
\hline 2015 & $\begin{array}{l}\text { (i) Nitrogen-doped } \\
\text { graphene/CNT composite, } \\
\text { (ii) N,P-doped carbon foam, } \\
\text { (iii) Carbon nanocages }\end{array}$ & $\begin{array}{l}\text { (i) Modified Hummers' method for the } \\
\text { GO fabrication [73] } \\
\text { (ii) Pyrolysis of a polyaniline aerogel } \\
\text { (iii) Hard templating method }\end{array}$ & $\begin{array}{l}\text { (i) ORR in acidic fuel cell [59], } \\
\text { (ii) ORR and OER [60], } \\
\text { (iii) ORR [61] }\end{array}$ \\
\hline 2016 & N,P-co-doped carbon networks & Soft template and Pyrolysis & ORR and HER [62] \\
\hline 2017 & Carbon-based metal-free nanomaterials & Solvothermal process & OER, ORR and HER [63] \\
\hline 2018 & $\begin{array}{l}\text { (i) N-doped hierarchical porous } \\
\text { carbon nanosheets, } \\
\text { (ii) N-doped porous carbon, } \\
\text { (iii) MOF-derived nitrogen-doped highly } \\
\text { disordered carbon }\end{array}$ & $\begin{array}{l}\text { (i) Template-free method, (ii) Pyrolysis, } \\
\text { (iii) Solvothermal method }\end{array}$ & $\begin{array}{l}\text { (i) ORR [64], (ii) Electrocatalytic } \mathrm{N}_{2} \text { reduction } \\
\text { [65], (iii)Electrochemical synthesis of } \\
\text { ammonia (ESA) through the nitrogen } \\
\text { reduction reaction (NRR) [66] }\end{array}$ \\
\hline 2019 & Nitrogen-doped carbon-based catalysts & Solvothermal method & Acidic oxygen reduction [67] \\
\hline 2020 & $\begin{array}{l}\text { (i) Tellurium-doped, mesoporous carbon } \\
\text { nanomaterials, (ii) Nitrogen-doped } \\
\text { metal-free nanomaterials, (iii) } \\
\text { Nitrogen-doped metal-free nanomaterials }\end{array}$ & $\begin{array}{l}\text { (i) Pyrolysis, (ii) Solvothermal, } \\
\text { (iii) Solvothermal }\end{array}$ & $\begin{array}{l}\text { (i) Bifacial dye-sensitized solar cells [68] (ii) } \\
\text { Bifunctional oxygen electrocatalyst for } \\
\text { ultrastable zinc-air batteries [69], } \\
\text { (iii) Selective catalytic oxidation of hydrogen } \\
\text { sulphide [70] }\end{array}$ \\
\hline 2021 & $\begin{array}{l}\text { (i) Oxygen- and nitrogen-doped metal-free } \\
\text { microalgae carbon nanoparticles, (ii) } \\
\text { Nitrogen-doped graphene/CNT composite }\end{array}$ & $\begin{array}{l}\text { (i) Potassium hydroxide }(\mathrm{KOH}) \\
\text { activation of Spirulina Platensis } \\
\text { microalgae, (ii) Pyrolysis }\end{array}$ & $\begin{array}{l}\text { (i) Hydrogen production from sodium } \\
\text { borohydride in methanol [71], (ii) ORR in } \\
\text { acidic fuel cell [72] }\end{array}$ \\
\hline
\end{tabular}




\section{Nitrogen-Doped Metal-Free Carbon Nanostructured Electrocatalysts}

\subsection{Nitrogen-Doped Carbon Nanotube Electrocatalysts}

The functionalized nanotubes garnered significant attention in the field of the reinforced and conductive plastics, sensing materials and photovoltaic materials as scanning probe microscopy tips and many more applications. There have been two broad methods to synthesize substituted N-doped CNTs: (a) in situ process for insertion of nitrogen atom into the CNTs during the reaction, only [74-78]; and (b) postfunctionalization of CNTs with nitrogen by using various precursors and compounds like organic moieties. However, the postfunctionalization method has not been well investigated until now [79-81]. These nanomaterials have also been synthesized using other potential synthetic strategies, viz., arc discharge, laser ablation and plasma etching [82-87]. However, these methodologies required higher temperature conditions and a limited type of nitrogen or carbon precursors. Moreover, rapid evaporation of precursors and application of nitrogen or ammonia atmosphere has been required. In the chemical vapor deposition (CVD) method, the process could completed at a lower temperature range with and without the presence of an organometallic catalyst and by using a wide range of carbon or nitrogen precursors. This method could produce 20-25 g of N-carbon nanotubes per gram of catalyst, and nitrogen atoms are embedded into the hexagonal carbon network at various ratios with 10 atoms [81]. In the literature, nitrogen incorporation has been reported with nitrogen contents of $<1$ atom $\%$ to 20 atom $\%[75,88,89]$. Highly oriented nanotubes with regular diameter and bond-length were termed in literature as "carpet-like" structures [90]. In this work, nitrogen was incorporated into the already synthesized CNT structure; however, this synthesis method was depicted as highly complex and tedious with multistep techniques. The first step is initiated with a chemical oxidation process of tips or structural defects of CNTs, followed by coupling with other molecules through carboxylic, carbonyl and/or hydroxyl groups. The covalent functionalization via bond formation to the $\pi$-conjugated structure of CNT leads to the rehybridization of $\mathrm{sp}^{2}$ bond to $\mathrm{sp}^{3}$. In this type of structure, nitrogen is attached to carbon following two different manners: (a) pyridine-type nitrogen, in which each nitrogen atom is bonded to two different carbon atoms, leading to the formation of cavities within the side wall of the tube, and (b) substitution $\mathrm{N}$, in which a nitrogen atom bonds with three $\mathrm{C}$ atoms, as presented in Figure 2. Nitrogen contains an additional electron in its structure, in comparison to the carbon network; therefore, a nitrogen-incorporated CNT structure usually exhibits metallic properties [90-92]. The nitrogen group can also enhance the reactivity on the graphene in comparison to the pure CNT structures, which results in the potential applications of these materials in fast-responsive sensing technology; as effective field-emissions sources; and as polystyrene, epoxy composites, protein and nanoparticle immobilizers [78,93-96]. The most popular covalent functionality, with the application of plasma etching or by $\mathrm{HNO}_{3} / \mathrm{H}_{2} \mathrm{SO}_{4}$ treatment, includes carbonyl or carboxyl groups [97].

The plasma etching technique is essentially applicable during functionalization processes in a nitrogen atmosphere. In the next step, carboxyl groups are acylated with thionyl chloride to establish a basis for different amine compounds [98] or to combine with DNA and proteins $[99,100]$. The noncovalent functionalization is mostly conducted by adsorption or through the wrapping of the CNTs in polymer polynuclear aromatic compounds, surfactants or biomolecules by Vander Waals forces and $\pi-\pi$ interactive forces. Other synthetic approaches of CNTs include the arc evaporation method of graphite [82,101]. The noncovalent methods are more favourable over covalent, as the chemical functionalization can be performed on the CNTs without affecting their structures and electronic networks on the nanotubular structures. 


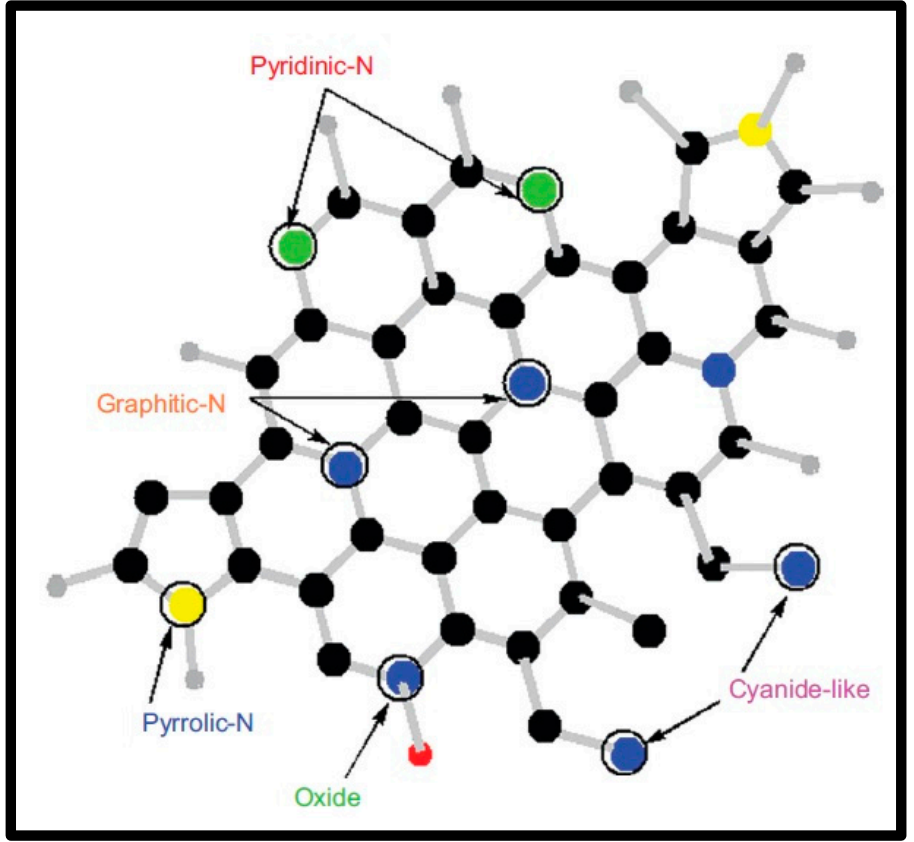

Figure 2. Nitrogen doping in the carbon nanomaterial structures (Reproduced with permission from S. Majeed et al. [89]).

\subsubsection{Chemical Vapour Deposition (CVD) Method}

Chemical vapour deposition (CVD) is a technique to synthesize carbon nanotubes in bulk amounts, which involves the pyrolysis of different organic molecules, viz., $\mathrm{CH}_{4}$, $\mathrm{C}_{6} \mathrm{H}_{6}, \mathrm{C}_{2} \mathrm{H}_{2}$, etc., in inert atmosphere over $\mathrm{Ni}, \mathrm{Co}, \mathrm{Fe}$, etc., catalysts [102,103]. Due to the simplicity and cost-effectiveness of CVD, researchers prefer to follow this methodology during the functionalization process.

In 1997, Dai et al. introduced $\mathrm{H}_{2} \mathrm{O}$ plasma etching technology to generate surface patterns of polar groups with oxygen [104]. This methodology was further followed by $\mathrm{Yu}$ et al. [86] to develop $\mathrm{SiO}_{2}$ nanoparticles as the metal-free catalysts, in which a $\mathrm{SiO}_{2} / \mathrm{Si}$ wafer with a $30 \mathrm{~nm}$-thick $\mathrm{SiO}_{2}$ coating was employed with $\mathrm{H}_{2} \mathrm{O}$ plasma etching at $30 \mathrm{~W}, 250$ $\mathrm{kHz}$ and 0.62 Torr for $20 \mathrm{~min}$. This plasma-etched substrate was placed into a tube furnace for the synthesis of CNTs by using the CVD method. Figure 3 represents the schematic diagram to represent the growth of CNTs. These materials acted as potential electrocatalysts in an oxygen reduction reaction analysed in $0.5 \mathrm{M} \mathrm{H}_{2} \mathrm{SO}_{4}$ solution saturated with $\mathrm{N}_{2}$ or $\mathrm{O}_{2}$. Figure 4 shows the various electrochemical studies conducted in this work. All the electrocatalytic studies have shown excellent results and long-term stability in an acidic medium in comparison to undoped CNTs. The authors also claimed that, due to the highly generic nature of the plasma etching technique, this synthetic strategy can be well accepted in various fields, from energy applications to electronic and biomedical systems [86]. Kim et al. mentioned a similar synthesis process in an Ar atmosphere at $800{ }^{\circ} \mathrm{C}$ for $1 \mathrm{~h}$ duration in which ferrocene, pyridine or ethylenediamine used as a catalyst carbon and nitrogen precursor, respectively [50]. TEM images of bamboo-structured N-doped CNTs (NCNTs) are presented in Figure 5. These products were used as excellent electrocatalysts in ORR of fuel cell applications. The same research group reported synthesis of nitrogendoped CNTs by following a single step the CVD method in which either ferrocene or iron (II) phthalocyanine was used as the catalyst and pyridine as the carbon and nitrogen precursor, respectively. These materials have also used successfully as ORR electrocatalysts [105]. 


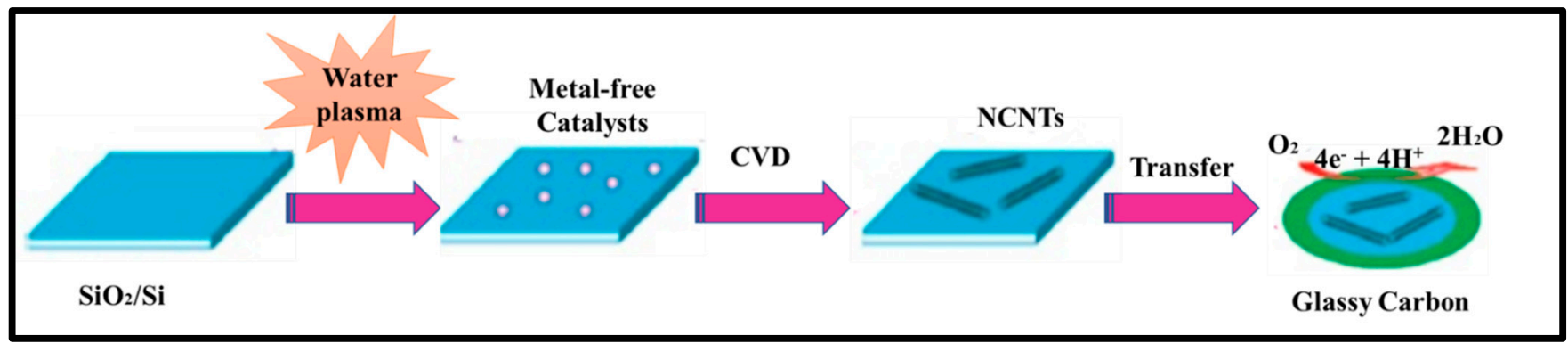

Figure 3. N-doped metal-free CNTs as ORR electrocatalysts (Reproduced with permission from Chen et al. [86]).
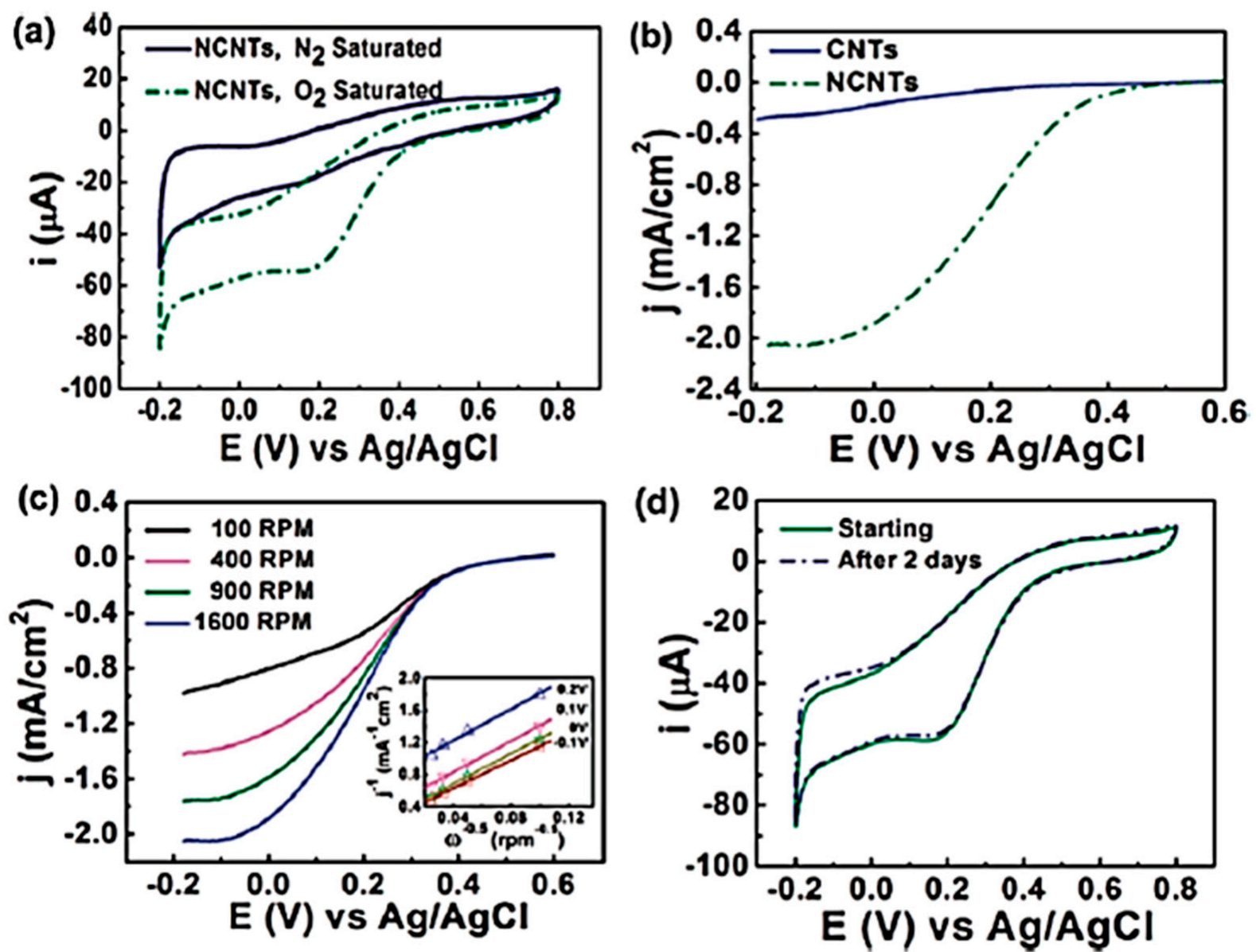

Figure 4. Electrochemical studies in ORR under acidic medium with N-doped metal - free CNTs (Reproduced with permission from Yu et al. [86]).

In 2011, Feng et al. [52] reported N-doped CNTs to be effective electrocatalysts in microbial fuel cells (MFCs), boasting cost-effectiveness and long durability. Moreover, these materials were depicted as more effective cathodic catalysts than the commonly used platinum catalyst with a maximum power density value of $1600 \pm 50 \mathrm{~mW} \cdot \mathrm{m}^{-2}$. These N-doped CNTs have shown a lower drop in the percentage of power density than that of Pt/C over 25 cycles. Another research group reported the CVD synthesis floating catalyst method of nitrogen-doped carbon nanotubes using ferrocene/aniline together with toluene as an added carbon source [106]. Yang et al. synthesized aligned nitrogen-doped CNT bundles over $700-800{ }^{\circ} \mathrm{C}$ by taking ammonium-exchanged zeolite- $\beta$ as the substrate material, ferric nitrate as the catalyst and acetonitrile as the carbon precursor [107]. In the same year, He et al. reported controllable synthesis of aligned CNx with a large surface area 
by pyrolyzing $\mathrm{CH}_{3} \mathrm{CN} / \mathrm{Fe}\left(\mathrm{C}_{5} \mathrm{H}_{5}\right)_{2}$ on $\mathrm{SiO}_{2}$ and $\mathrm{Si}$ substrates over the temperature range of 750-900 ${ }^{\circ} \mathrm{C}$. The specific diameters of CNTs diminished on Si substrates in comparison to a well-documented rise with temperature on silica, as the growth process followed different mechanisms of formation of catalyst particles [108]. Kim et al. developed N-doped, doublewalled CNTs using chemical vapor deposition in which a $\mathrm{CH}_{4} / \mathrm{NH}_{3} / \mathrm{Ar}$ mixture flowed with the rate of 50/10/500 sccm on $\mathrm{MgO}$-supported catalyst powders at the temperature of $850{ }^{\circ} \mathrm{C}$ for $10-30 \mathrm{~min}$. of duration [109]. The synthesized CNTs are formed with a diameter of 10-20 nm. The SEM and HRTEM images of N-doped double walled-CNTs presented in Figure 6.

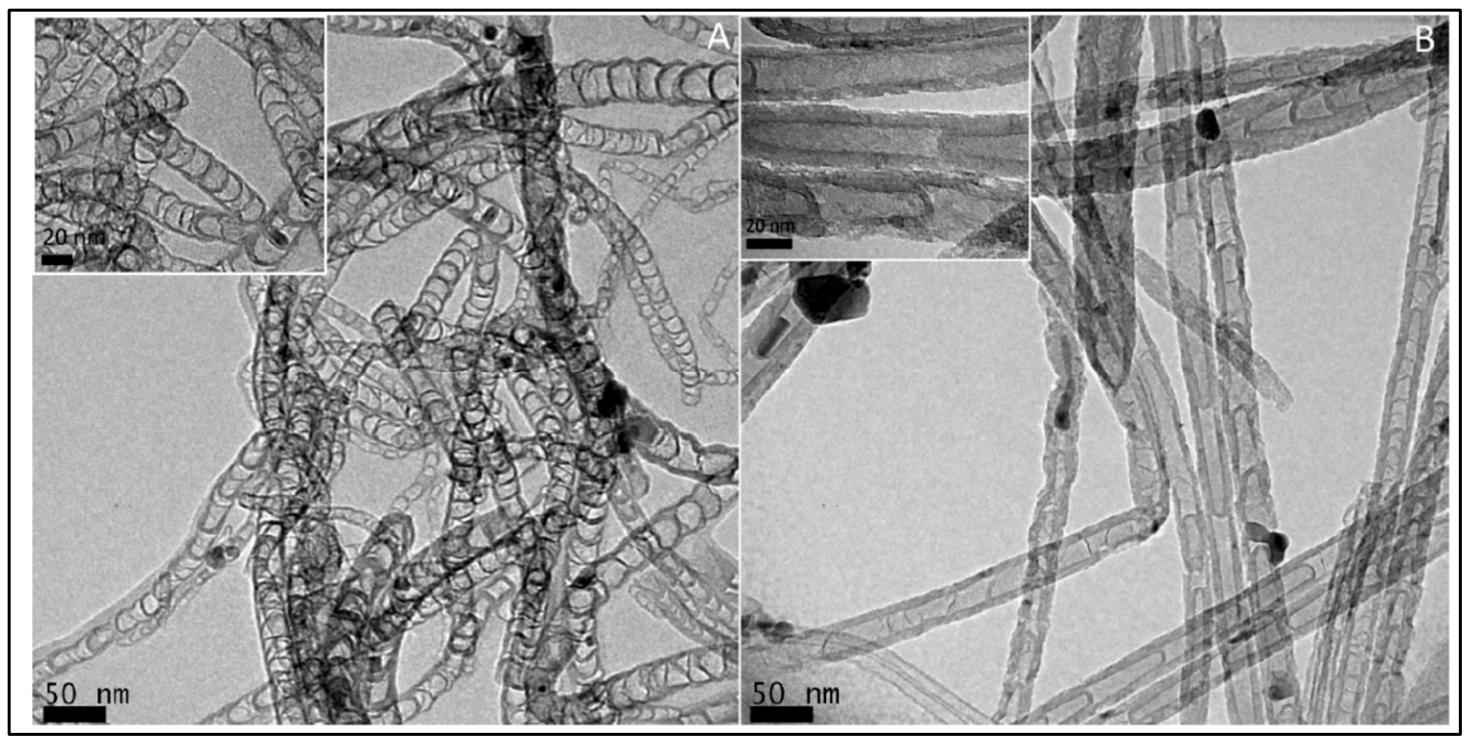

Figure 5. TEM images of bamboo-structured NCNTs (A) ethylenediamine-NCNTs (B) PyridineNCNTs (Reproduced with permission from Chen et al. [50]).
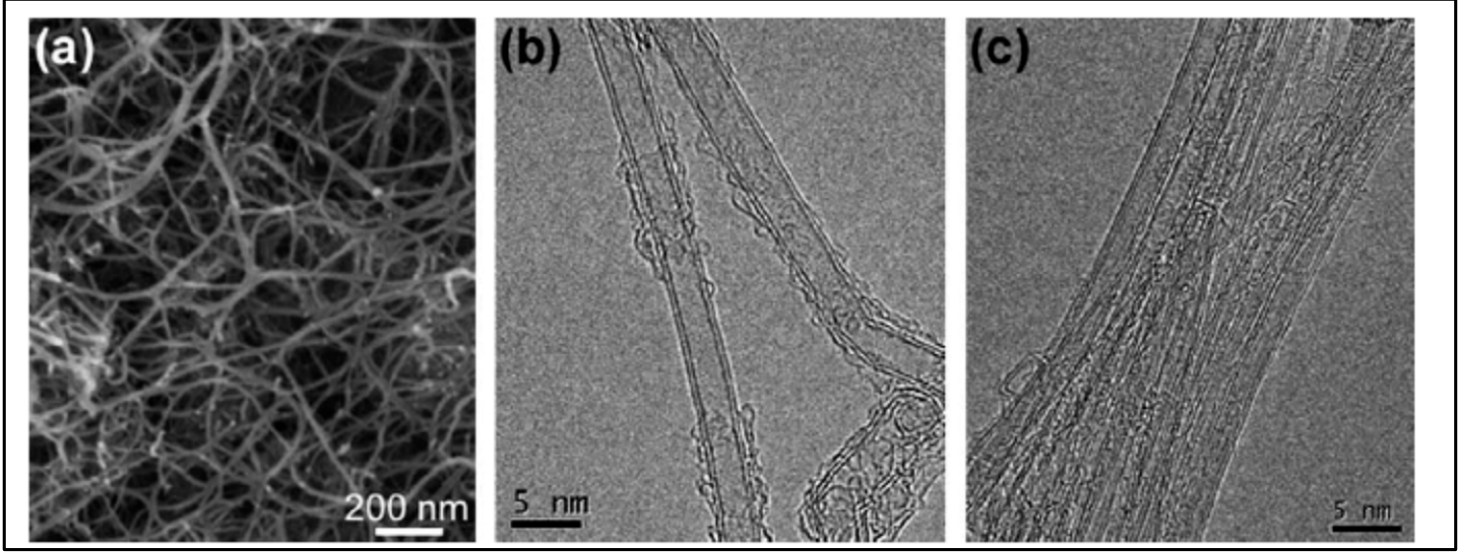

Figure 6. (a) SEM image shows the nanotube bundles with a diameter of 10-20 nm (b) HRTEM image reveals that the bundles are consisted mainly of double walled CNTs DWNTs. (c) A magnified image showing the outer diameter in the range of 1.5-2 $\mathrm{nm}$ (Reproduced with permission from Kim et al. [109]).

In recent years, $\mathrm{Li}$ et al. reported a one-step CVD method to synthesize threedimensional nitrogen-doped CNT/graphene hybrid material on nickel foam [110]. In this study, nickel foam and melamine were mixed with the mass ratio of 1:5 kept in a horizontal quartz tube reactor and heated to within the temperature range of $600-800{ }^{\circ} \mathrm{C}$ in a hydrogen atmosphere for around $20 \mathrm{~min}$ at a flow rate of $70 \mathrm{sccm}$. In 2020, another 
research group mentioned a two-step synthetic strategy to develop nitrogen-doped carbon nanotubes derived from $\mathrm{g}-\mathrm{C}_{3} \mathrm{~N}_{4}$ [111]. In this case, exfoliated graphitic carbon nitride was functionalized with nickel oxides and placed in a ceramic boat to keep in the tubular furnace at $900{ }^{\circ} \mathrm{C}$ in a nitrogen atmosphere. Hydrogen was introduced for $3 \mathrm{~h}$ in the first step and ethylene for $10 \mathrm{~min}$ for the reduction process. The synthesis of $\mathrm{N}$-doped MWCNTs with straight structure was reported by $\mathrm{Xu}$ et al. by using phthalocyanine derivatives [112] and the mixture of ethylene/hydrogen and ammonia at around $680{ }^{\circ} \mathrm{C}$ in a presence of alumina-supported iron catalysts in a CVD furnace [113]. The amount of nitrogen incorporated into CNT can be controlled by using different amounts of nitrogen precursors $[80,114]$. The rate in which nanotubes grow during synthesis can be enhanced with the increase in its precursor significantly, resulting into the increase in intensity ratio of the $\mathrm{D}$ to $\mathrm{G}$ bands in Raman spectra. The inner structure of N-doped CNTs constitutes regular morphological transformation from the straight and smoother walls $(0$ atom $\% \mathrm{~N})$ to 1.5 atom\% N-containing, bamboo-structured CNTs; further, it changed to corrugated structures with 3.1 atom\% and higher nitrogen [115]. It has been analysed by Wang et al. that, during the synthesis of N-doped CNTs, when melamine is used as the C/N initiator, it can incorporate 20 atom $\%$ nitrogen. In this type of synthesis method, the $\mathrm{N}$ atom present in the reaction medium self-assembled with gaseous carbon without any assistance from metal [116]. These N-doped CNTs were utilized successfully as ORR electrocatalysts in methanol fuel cells measured in alkaline media. Figure 7 shown the various electrochemical studies of NCNT/GC.
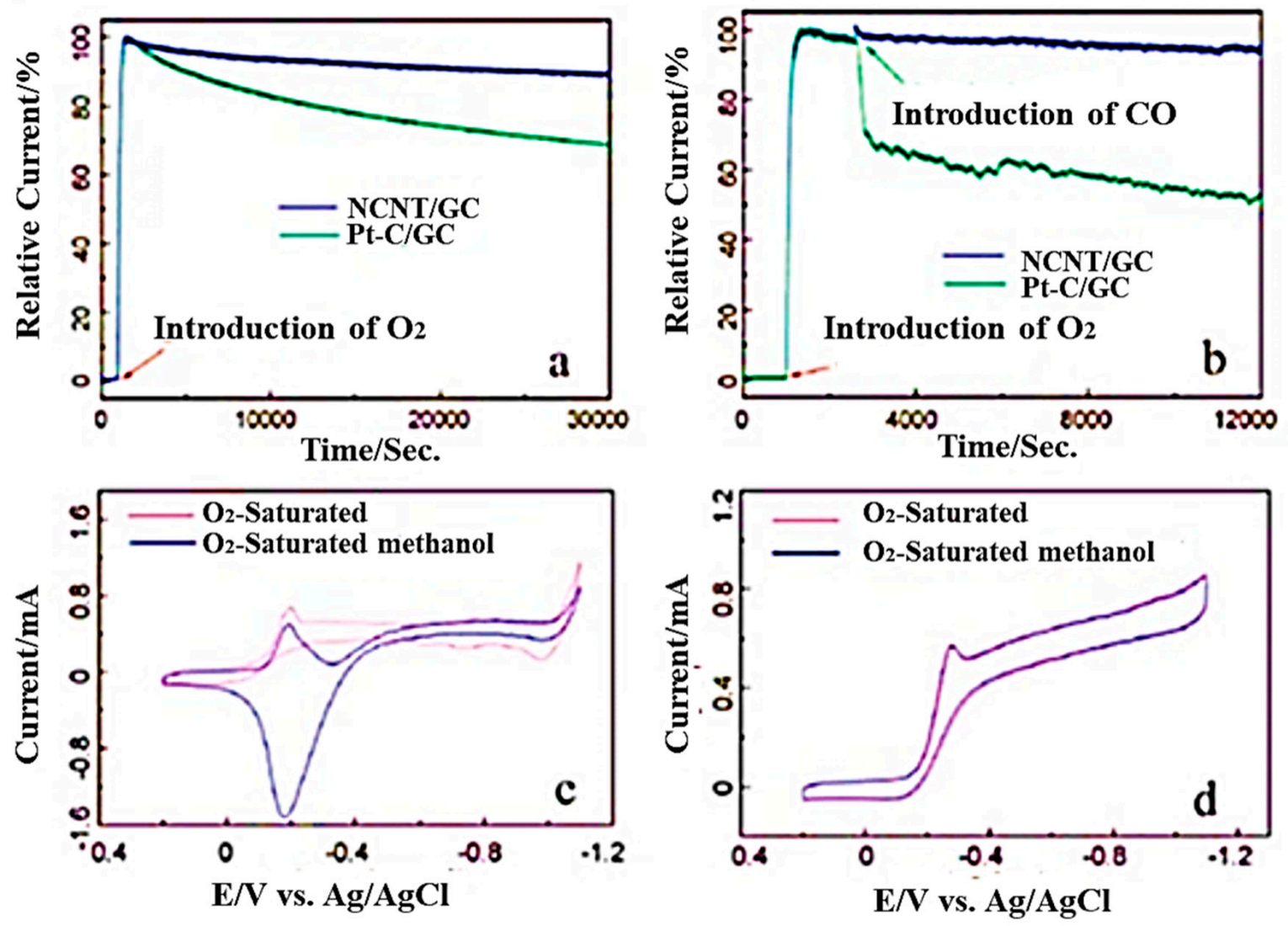

Figure 7. (a) Chronoamperometric studies with NCNT/GC and Pt-C/GC electrodes in oxygen saturated 0.1M KOH. (b) Responses after the introduction of $10 \% \mathrm{CO}$. (c) Cyclic voltammograms of $\mathrm{Pt} / \mathrm{GC}$ and (d) cyclic voltammograms of NCNT/GC electrodes oxygen saturated $0.1 \mathrm{M} \mathrm{KOH}$, with and without $3 \mathrm{M}$ methanol solution (Reproduced with permission from Wang et al. [116]). 
The incorporation of nitrogen atoms usually shows very strong ability to promote the self-assembled CNTs. Nitrogen could create highly active sites in carbon networks, which results in remarkable electrocatalytic performance comparable to traditional Pt-based materials as electrocatalysts. Their high activity with excellent stability and selectivity always made N-doped CNTs better electrocatalysts in this purpose. These materials were also strongly resistant to $\mathrm{CO}$ poisoning, had a robust structure and were economically favourable. Due to doping in CNT structures, a basic shape could be transformed from a hollow cylinder to a bamboo-shaped structure. The resultant doped materials contained plenty of compartments, the lengths of which gradually decreased with variation in $\mathrm{N}$ concentration [117].

\subsubsection{Chemical and Electrochemical Modification Method}

The chemical modification methods to synthesize nitrogen-doped CNTs included two different approaches, viz., covalent and noncovalent. During the covalent modification, oxygen-containing functional groups, viz., carboxyl and hydroxyl, were formed and generated on the surface. Among the functional groups, carboxylic acid groups were chosen as the best options, as they could easily proceed a variety of reactions in the modification process and could be easily developed using different oxidizing treatments, e.g., ozonolysis, sonication in nitric and sulfuric acid, refluxing in nitric acid, etc. In the next step, carboxyl-functionalized CNTs were grafted with the functional moieties by using the terminal oxidation process following various mechanisms from the defect site, from chemistry oxidation reactions and esterification/amidation processes to the already oxidized CNTs [118,119], mechanochemical modification [120,121], ionic liquids, cycloaddition reactions [122,123], electrochemical modification reactions, diazotization [124] and radical additions [125].

The efficient and successful doping and tailoring technologies in CNTs involved the controlling of redox properties of the dopant. Nitrogen-doped CNTs have excellent electrocatalytic activity compared to Pt electrodes, which could be acclaimed by the formation of additional active sites on the surface of the materials and has led to better dispersion of the Pt particles over the N-CNT and performed better in methanol oxidation [126]. From the results, it was analysed that doped CNTs as electrode materials always enhanced the output power of the thermoelectrochemical cells. Doping enhanced the electrochemical active surface area (ESCA) values in the CNT electrodes in proportional way. Wei et al. reported doped CNTs mixed with glutaraldehyde functionalized chitosan (GCS), which depicted an improved biocompatibility and higher conductivity in enzyme immobilization process, due to the enhanced kinetics from the N-CNTs [127]. The electrochemical modification process was carried out through two types of coupling reactions, working under oxidative or reductive conditions. In 2002, Kooi et al. worked on anodic coupling reaction to the SWCNTs by using two different aromatic amines, viz., 4-aminobenzylamine and 4-aminobenzoic acid [128]. The noncovalent functionalization process could be carried out through the porphyrin assembled on the N-doped MWCNTs via the Fe-N coordination. Tu et al. reported this noncovalent modification by porphyrin, which led the MWNTs insoluble in water, however, performed well as catalysts and biosensors [129].

\subsection{Nitrogen-Doped Carbon Hollow Spheres}

The carbon spheres usually referred to the spherical shaped carbon in semicrystalline or crystalline form, and constituted solid, hollow or core-shell morphological structures. Researchers have paid huge attention to nitrogen-doped hollow spherical structures in recent years due to their lower density, greater surface area values, better electrical conductivity, and excellent structural stability. In 2012, Zhu et al. developed a hierarchical porous hollow carbon nanospheres as an oxygen reduction electrocatalyst for zinc-air batteries, which contained active pyridinic- $\mathrm{N}$ and graphitic- $\mathrm{N}$ by using polystyrene spheres and aniline as the corresponding template and precursor [130]. Gu et al. reported N-doped porous carbon spheres with excellent porosity characteristics, which was used as a potential electrocatalyst 
in ORR. The unique spherical structures with remarkable stability and recyclability made these materials the most promising ORR electrocatalysts [131]. Hydrothermal carbonization method was adopted to make these materials by using biomass glucose, followed by treatment in ammonia and by subsequent activation treatment. Another research group reported the development of N-doped carbon nanodots @ nanospheres, which were applied as efficient electrocatalyst in ORR, in which high electrocatalytic activity was shown with an onset potential of $-0.08 \mathrm{~V}$, and they showed greater durability and greater resistance to the methanol cross-over effect; these results were comparable to commercially available $\mathrm{Pt} / \mathrm{C}$ electrocatalyst. These N-doped carbon nanodots of sizes 2-6 nm were successfully formed by using the hydrothermal method from natural biomass (e.g., fresh grass) at $180{ }^{\circ} \mathrm{C}$ for $10 \mathrm{~h}$ duration. Furthermore, these carbon nanodots were subsequently immobilized onto functionalized microporous carbon nanospheres (MCNSs) with an average diameter of $\sim 100 \mathrm{~nm}$ and a surface area of $241 \mathrm{~m}^{2} \mathrm{~g}^{-1}$ via a simple hydrothermal process to self-assemble a carbon-based nanocomposite (N-CNDs@MCNSs) in the presence of oxygen (O)-containing surface functional groups [132]. Today, a significant number of research works were carried out on nitrogen encapsulation on metal/metal oxides/carbon nanosphere materials potentially applied as electrodes or electrocatalysts [133-140]. In the current review, those works were not considered, as they are not metal-free nanostructured materials.

\subsection{Nitrogen-Doped Graphene Electrocatalysts}

Graphene has been two-dimensionally structured with $\mathrm{sp}^{2}$ hybridized carbon with interesting physical and chemical characteristics. To achieve the desired performance in electrochemical and biochemical applications, nitrogen-enriched graphene materials were synthesized using a wide range of methodologies [141-151]. In 2011, Zhang et al. developed N-doped graphene by thermally annealing graphene oxide in the presence ammonia [152]. Another research group reported a facile and catalyst-free method to develop large-scale synthesis of nitrogen-doped graphene with $10.1 \mathrm{wt} \%$ nitrogen content by using the economically favourable industrial material melamine as the nitrogen source [153]. Sheng et al. synthesized nitrogen-doped graphene using the solvothermal method with the reaction between tetrachloromethane with lithium nitride under mild conditions [154]. Figures 8 and 9 present the schematic diagram to synthesize these materials and their potential electrocatalytic applications in ORR under alkaline media, respectively. Another simple way to produce $\mathrm{N}$-doped graphene nanosheets following the solvothermal route is via the reaction between graphene oxide and urea with a nitrogen content of 10.13 atom\% [155]. Temperature played a pivotal role in the solvothermal process during the doping of nitrogen in the graphene network [152,153]. Another research group developed pyrrolic and pyridinic type nitrogen incorporation in a graphene structure at 300 and $500{ }^{\circ} \mathrm{C}$, respectively, with the annealing treatment of graphene oxide in the presence of glycine and $\mathrm{AgNO}_{3}$ [156]. This particular methodology produced N-doped graphene with 13.5 atom\% of nitrogen into the materials. The CVD method was also adopted by using methane and ammonia; these materials were utilized as metal-free electrocatalysts in ORR applied in fuel cells [157]. Many research groups have also applied the arc discharge method in $\mathrm{H}_{2}$ and He atmosphere and under pyridine vapour to produce the nitrogen-doped graphene structure [158,159].

Yang et al. reported synthesis of N-doped graphene, the result of which was successfully demonstrated as highly efficient metal-free bifunctional electrocatalysts in the oxygen reduction and evolution reaction [160]. In this report, e- donating quaternary nitrogen sites were responsible for ORR; in contrast, e- withdrawing pyridinic nitrogen acted as active sites in OER, resulting into greater transports of electrons and electrolytes [160]. The schematic diagram to synthesize N-doped graphene nanoribbon networks shown in Figure 10 [160]. 


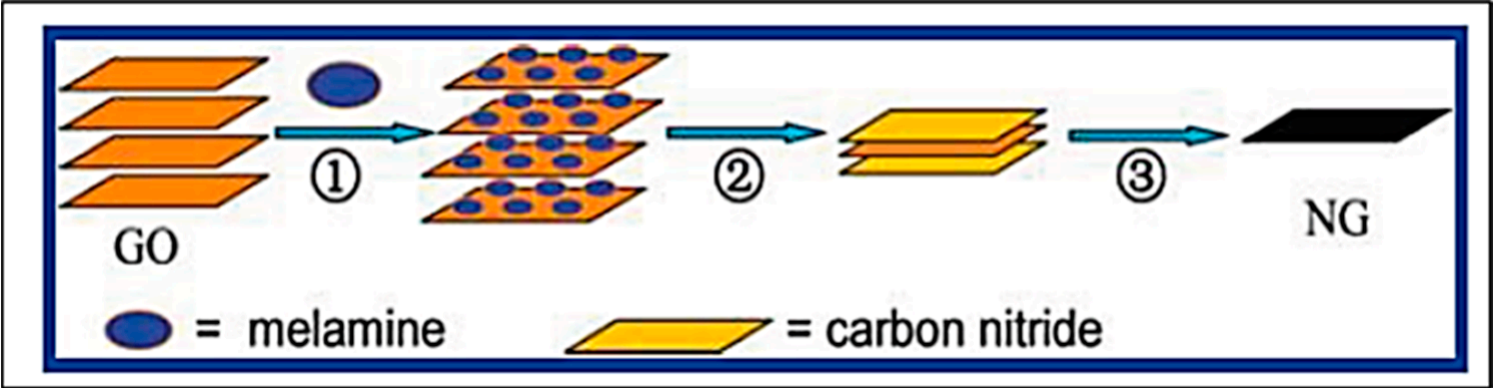

Figure 8. Schematic diagram of nitrogen doping method with melamine in the GO layer (Reproduced with permission from Sheng et al. [154]).

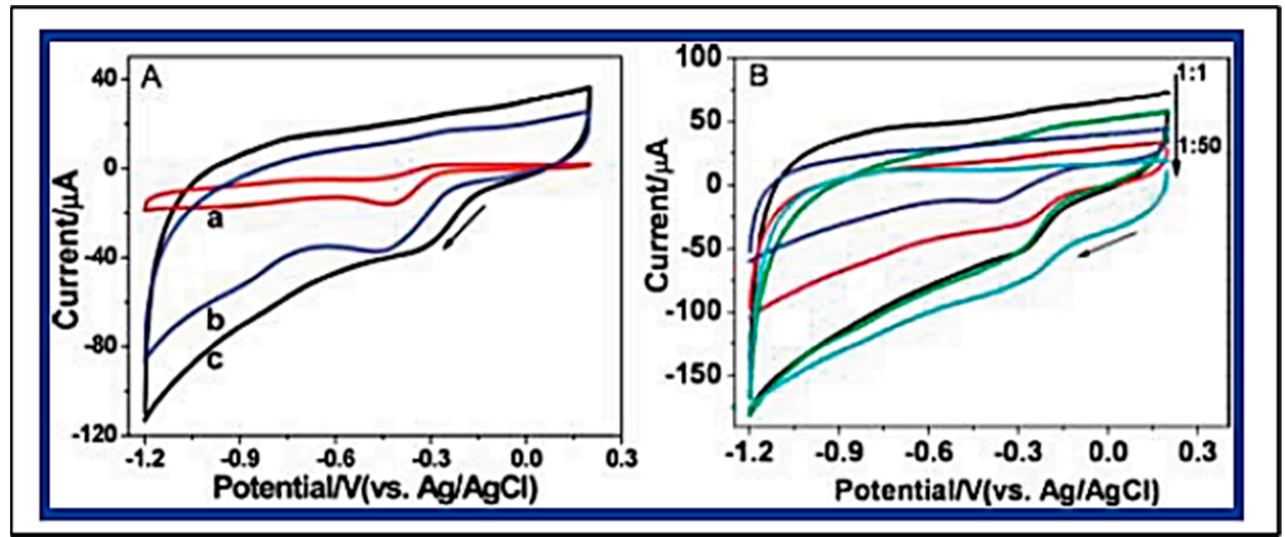

Figure 9. (A) Typical cyclic voltammograms (CVs) for ORR obtained at a bare GCE (a), graphene/GCE (b), and NG5/GCE (N\% = 7.1\%) (c) in $\mathrm{O}_{2}$ saturated $0.1 \mathrm{M} \mathrm{KOH}$ aqueous solution. (B) CVs for ORR at NGs, synthesized with different mass ratio of GO and melamine (1:1, 1:2, $1: 5,1: 10,1: 50$ ) at $800{ }^{\circ} \mathrm{C}$, modified GCE in $\mathrm{O}_{2}$ saturated $0.1 \mathrm{M} \mathrm{KOH}$ aqueous solution. (Reproduced with permission from Sheng et al. [154]).

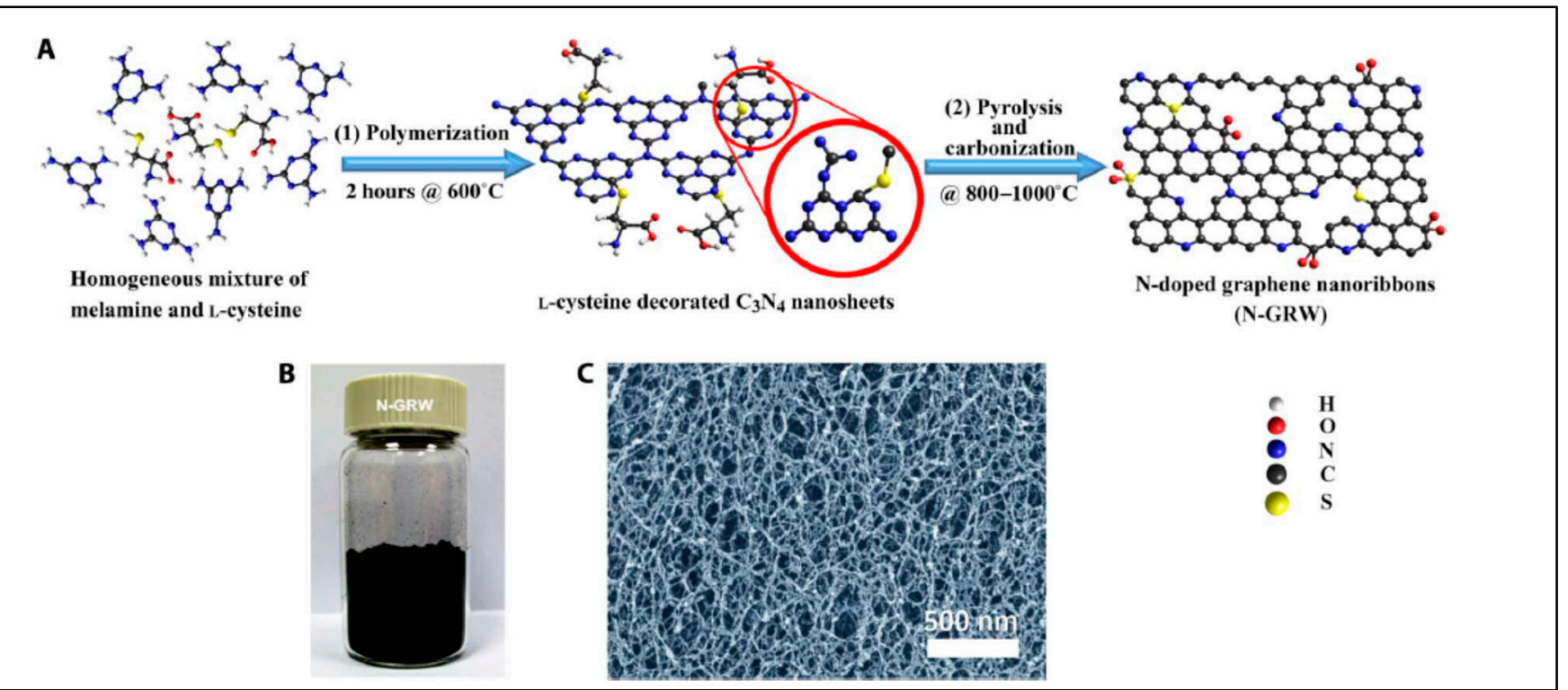

Figure 10. Synthesis of N-doped graphene nanoribbon networks (GRW). (A) Synthesis steps: (1) polymerization at $600{ }^{\circ} \mathrm{C}$ for $2 \mathrm{~h}$, and (2) pyrolysis and carbonization at $800^{\circ}$ to $1000^{\circ} \mathrm{C}$. (B) Digital photograph of the as-synthesized N-GRW. (C) Scanning electron microscopy (SEM) image of the as-synthesized N-GRW (Reproduced with permission from Yang et al. [160]). 
Liu et al. synthesized pyrrolic-nitrogen doped graphene, which was successfully adapted as carbon-free electrocatalysts in electrocatalytic reduction of carbon dioxide to formic acid in their comparative study with the computational method [161]. Earlier, Ju et al. developed nitrogen-doped graphene nanoplatelets as potential metal-free, counterelectrode materials used in organic dye-sensitized solar cells [162]. Rahsepar et al. followed a hybrid hydrothermal-microwave process to synthesize N-doped graphene, which exhibited remarkable electrocatalytic activity in ORR [163]. The number of catalytic sites was enhanced due to the incorporation of $\mathrm{N}$-atom into graphene. Maouche et al. developed nitrogen-doped graphene with porous structures, which was successfully employed as an ORR electrocatalyst [164]. In this work, a facile fabrication technology was carried out with graphitic carbon nitride $\left(\mathrm{g}-\mathrm{C}_{3} \mathrm{~N}_{4}\right)$ and graphene oxide (GO) as raw materials. Another research group utilized $\mathrm{N}$-doped graphene as an electrocatalyst in ORR under alkaline medium and in anion exchange membrane fuel cells [165].

\section{Sulphur and Sulphur-Nitrogen Co-Doped Metal-Free Carbon Nanomaterials as Electrocatalysts}

Nitrogen-doped carbon nanomaterials were accepted as potential electrocatalysts in ORR by researchers due to their charge transfer-induced performance using $\mathrm{N}$ contained in the graphitic framework, which further induced oxygen adsorption and reduction process at a comparatively lower overpotential value, which we briefly explained in the previous paragraph. In recent studies, other heteroatoms, viz., sulphur, phosphorus, boron and fluorine, were also studied to incorporate in carbon materials to promote their electrocatalytic activity in ORR as metal-free electrocatalysts in comparison to the undoped carbon nanomaterials [166-169]. However, dual doping of heteroatoms was believed to produce more effective electrocatalysts due to the synergistic effect between heteroatoms during ORR procedure in electrochemical performance and also in theoretical calculations. Their excellent synergistic effects induced the formation of higher numbers of catalytic sites with a remarkable reactant transport effect due to their hierarchical pore structures and greater electron transfer rate, which is generated by their three-dimensional continuous networked structures [170]. Li et al. mentioned that an optimal doping level could be the pivotal factor to control doping density and maximum catalytic performance in resultant materials [171]. In these types of nanomaterials, the total difference in electronegativity (d) generated from nitrogen and sulphur in comparison to what carbon might have generated indicates a more robust contribution of innovative nonelectroneutral sites in comparison to the monoheteroatom-doped structure $\left(\mathrm{d}_{\mathrm{C}}=2.55, \mathrm{~d}_{\mathrm{N}}=3.04\right.$ and $\left.\mathrm{d}_{\mathrm{S}}=2.58\right)$. These special types of materials were reported to be more favourable to positively charged sites in the oxygen surface adsorption process, resulting in better ORR activity [172]. However, the reported works were mostly on doping of heteroatoms on CNTs and/or graphene, which could not be as effective for their high cost and complicated synthesis methodologies.

In 2012, Wohlgemuth et al. reported the one-pot hydrothermal synthesis of sulphurand-nitrogen-doped carbon aerogels which were utilized as potential electrocatalysts ORR [173,174]. In this method, two co-monomers, viz., S-(2-thienyl)-L-cysteine (TC) and 2-thienyl carboxaldehyde (TCA), were used in S incorporation using the typical solvothermal method. Further, the samples were placed inside a furnace under $\mathrm{N}_{2}$ atmosphere and were flushed for half an hour before being heated to $900{ }^{\circ} \mathrm{C}$ at a heating rate of $10 \mathrm{~K} \mathrm{~min}^{-1}$. This secondary pyrolysis step was applied in tuning carbon aerogel conductivity and heteroatom binding states. They had also conducted comparative electrocatalytic studies of these materials with solely N-doped aerogels in ORR both in acidic and alkaline mediums. They found co-doped materials to be better potential candidates in electrocatalytic study, which might be affirmed due to the synergistic effect between nitrogen and sulphur [173]. Figure 11 represented the micrographs of sulphur-and-nitrogen-doped carbon aerogels. 


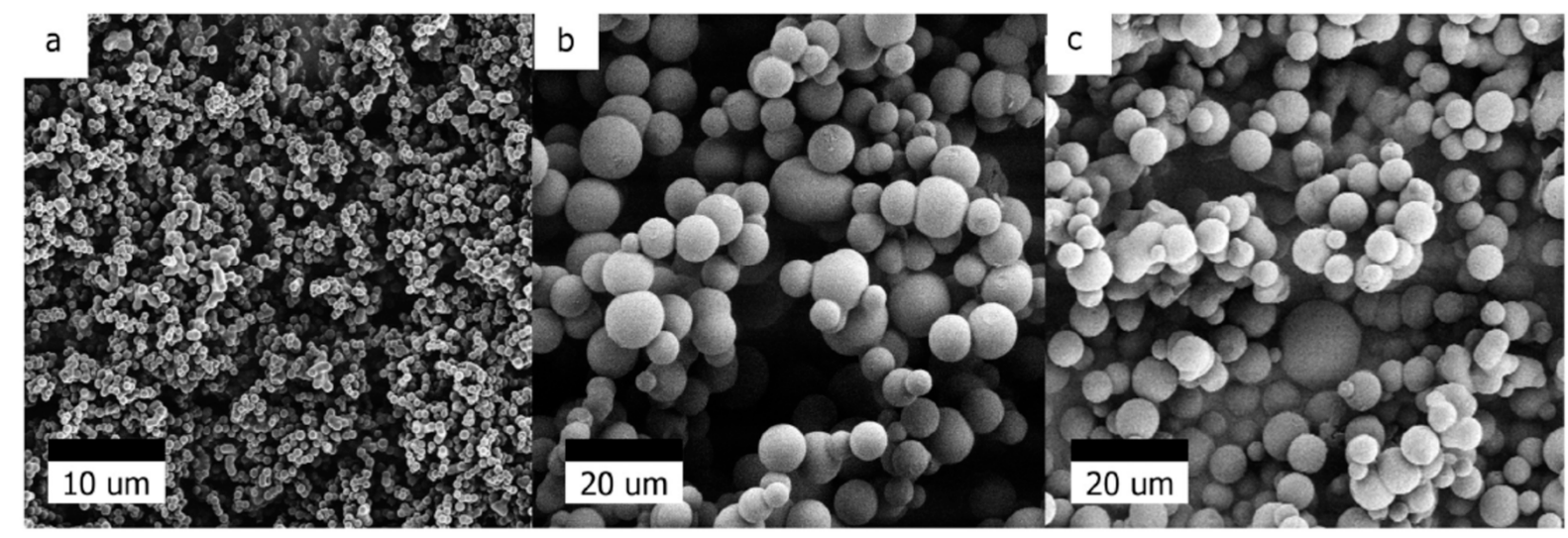

Figure 11. Scanning Electron Microscope images of products after hydrothermal carbonization method (a) pure glucose, (b) glucose with cysteine (Cys0.2) and (c) glucose with thienyl-cysteine (TCys0.2) (Reproduced with permission from Wohlgemuth et al. [174]).

Initially in 2002, the incorporation of sulphur into electrocatalytic performance was introduced by Wu et al. They had reported the development of sulphur-doped amorphous carbon as a potential cathode material by heat treatment of a mixture of polyacrylonitrile (PAN) and sulfuric acid [175]. Sulphur incorporation in the system enhanced the charge capacity value in close correlation with the increase in the size of graphite crystallites, interlayer distance and number of micropores. Choi et al. developed sulphur-doped carbons by using pyrolysis method of bioderived amino acids, viz., alanine, cysteine, glycine, niacin and valine, and utilized the materials as ORR electrocatalysts successfully in fuel cell applications. They had also synthesized a nitrogen-and-sulphur-co-doped catalyst by using cysteine, which performed best in acidic media in comparison to the commercially available Pt/C catalysts [176]. Previously, in 2006, Inamdar et al. introduced a new flame technology to synthesize spherical iron oxide nanoparticles by burning ferrocene solution using a spirit lamp [177]. The same research group synthesized carbon soot with various configurations using the flame pyrolysis method [178]. Thiophene was selected as the sulphur precursor material, and these nanomaterials were utilized as ORR electrocatalysts successfully. Park et al. reported high-quality S-graphene by using a lower content of oxygen-containing sulphur groups, with fluorinated graphite intercalation compounds (FGIC)-derived graphene as the starting material. This synthesis process was conducted at a comparatively lower temperature of $850{ }^{\circ} \mathrm{C}$ [179]. Zhang et al. developed graphenedoped $\mathrm{N}-\mathrm{S}$ using cysteine as a nitrogen/sulphur source material that was potentially utilized in ORR with better performance than Pt/C. [180]. Similar work was reported by Zhao et al. to synthesize N/S-co-doped hollow carbon microspheres with great electrocatalytic performance in alkaline media [181]. Wang et al. used residues from banana peel to develop porous carbons, which were co-doped with N/S [182]. These materials were used as ORR electrocatalysts tested in alkaline medium. As we know, carbon can be derived from various sources by following simple methods. Cassava (Manihot esculenta) is a crop which can generate a large amount of waste material as peel and pulp. It contributes over 700 MT waste materials in global upstream food waste [183]. Duran et al. used cassava residues in preparation of sulphur-doped metal-free electrocatalysts through a thermal functionalization with sulfuric acid which were used in ORR under alkaline media [184].

\section{Phosphorus- and Phosphorus-Nitrogen-Co-Doped Metal-Free Carbon Nanomaterials as Electrocatalysts}

Phosphorus contains the same number of valence electrons as the nitrogen atom; therefore, it shows similar chemical properties [185], although it has a greater atomic radius value and higher electro-donating ability than nitrogen, which makes it a better choice as a dopant to carbon materials. Despite of these advantages, fewer research groups have been involved in the development of phosphorus-incorporated novel carbon nanomaterials 
with improved surface area and catalytic activity. Mostly, the reported studies were on phosphorus incorporation in metal-metal oxide substrate. Figure 12 represents a schematic diagram of P-doped, multilayered, graphene-based metal nanospheres using the solvothermal method. In 2012, Yang et al. demonstrated the novel structured, P-doped, ordered mesoporous carbon (POMC) as a potential electrocatalyst in alkaline medium for ORR [185]. In this typical process, a mixture solution of triphenylphosphine (TPP) and phenol was infiltered into an SBA-15 template at room temperature and pyrolyzed at $900{ }^{\circ} \mathrm{C}$ in $\mathrm{Ar}$ media, following the removal of the template by etching with HF to obtain silica-free POMC. The synthetic strategy with their micrograms and electrochemical studies is shown in Figure 13. In 2013, Prasad et al. reported the microwave-assisted one-pot synthesis of metal-free N-and-P-dual-doped nanocarbon as an electrocatalyst in ORR under alkaline medium [186].

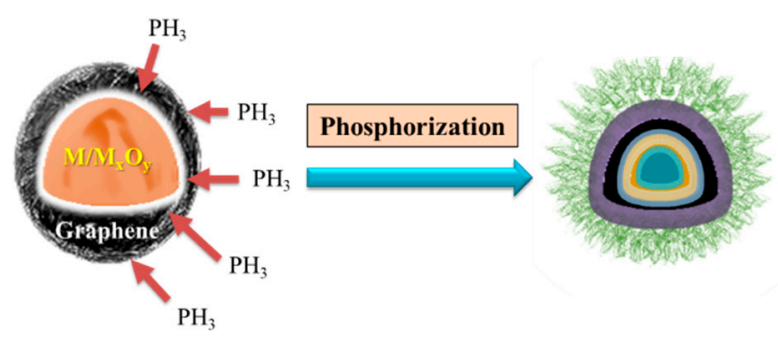

Figure 12. Schematic diagram of synthesis of P-doped, graphene-based, multilayered metal nanospheres by the solvothermal method.

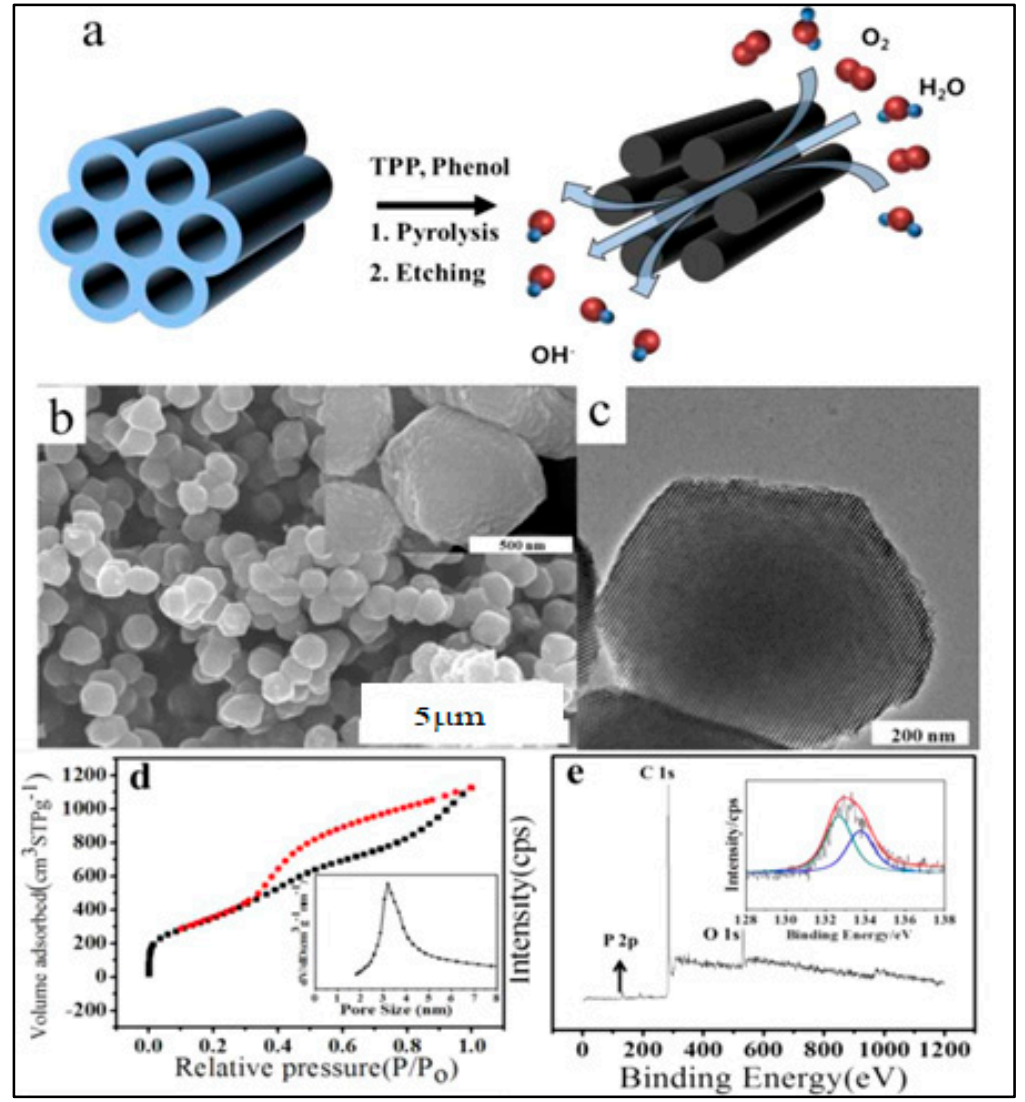

Figure 13. (a) Schematic illustration of POMC preparation, (b) FESEM image with an inset showing magnified image of POMC-3, (c) TEM image, (d) N2 sorption isotherms with an inset showing pore size distribution and (e) XPS survey scan and P 2p spectrum of POMC-3. (Reproduced with permission from Yang et al. [185]). 
In 2013, Li et al. synthesized P-doped graphene nanosheets by thermal annealing a homogeneous mixture of graphene oxide (GO) and BmimPF6 ionic liquid [187]. This innovative one-step method was economical and simple but scalable for mass production of P-doped graphene. These materials with phosphorous doping of 1.16 at $\%$ were proved to be better electrocatalysts in comparison to the commercial $\mathrm{Pt} / \mathrm{C}$ catalyst in ORR under alkaline medium [187]. A similar method was adopted by Qiao et al. to develop $\mathrm{N}$-and-P-dual-doped, reduced GO by pyrolyzing a homogeneous mixture of GO and diammonium hydrogen phosphate [188]. This material performed well as ORR electrocatalysts in alkaline medium following a four-electron pathway. A novel nanocasting method using platelet-ordered mesoporous silica as a template was adopted by Yang et al. in 2014 to develop P-doped, platelet-ordered, mesoporous carbon as excellent ORR electrocatalysts in alkaline media [189]. Nitrogen-and-phosphorus-co-doped, dual-doped hierarchical porous carbon foams were reported as efficient electrocatalysts in ORR developed through co-pyrolysis nitrogen- and phosphorus-containing precursors and poly(vinyl alcohol)/polystyrene (PVA/PS) hydrogel composites as in situ templates [190]. Yu et al. developed vertically aligned CNT arrays with co-doping of nitrogen and phosphorus using the chemical vapour deposition method [191], which exhibited excellent electrocatalytic stability and activity in ORR [191]. The electrochemical results had clearly shown enhanced electrocatalytic activity with co-doping (Figure 14).
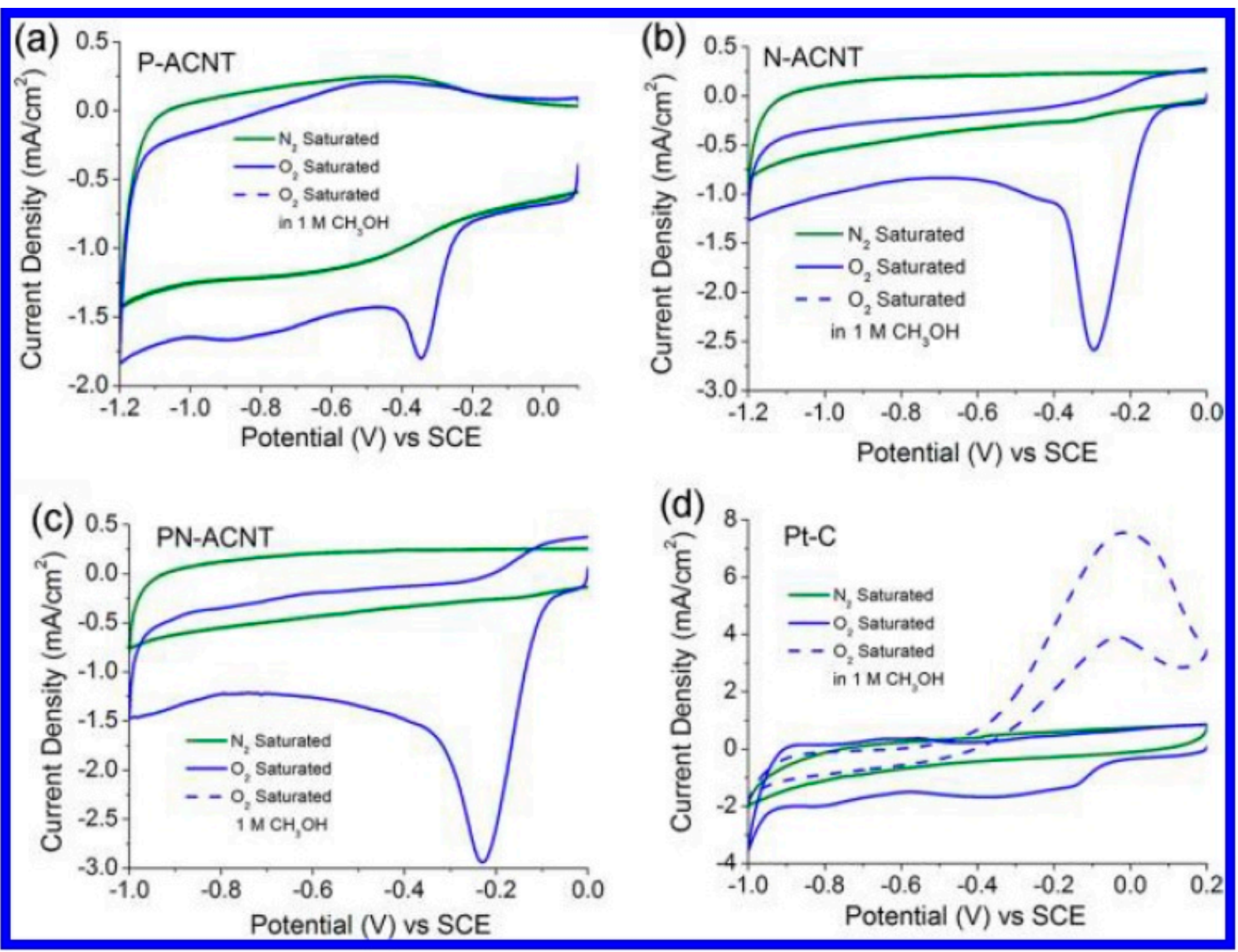

Figure 14. Cyclic Voltammograms for ORR in the presence of (a) phosphorus-, (b) nitrogen- and (c) phosphorus-nitrogen-doped CNTs; (d) Pt-Carbon electrocatalysts (Reproduced with permission from Yu et al. [191]). 


\section{Boron- and Boron-Nitrogen-Doped Metal-Free Carbon Nanomaterials as Electrocatalysts}

Nitrogen- and phosphorus-doped carbon nanomaterials have been most extensively investigated in the literature, whereas S, Se, B and I have also been reported as potential electrocatalysts [192,193]. In 2011, Yang et al. reported synthesis of boron-doped carbon nanotubes as efficient electrocatalysts in ORR [194]. Many research groups reported the synthesis of boron-and-nitrogen-co-doped carbon nanomaterials, although their intrinsic synergistic effects have not been discussed yet. Zou et al. mentioned the influence of co-doping in catalytic applications through mathematical modelling [195]. However, a competent synthetic strategy should be established to anchor nitrogen and boron onto the appropriate sites of the carbon structure instead of establishing the $\mathrm{N}-\mathrm{B}$ bond. Many researchers reported N,B-co-doped electrocatalysts, although their catalytic activity was not strong [196-199]. In contrast, high-performing electrocatalysts followed complicated synthetic strategies. Later, Zhou et al. synthesized a N,B-co-doped carbon catalyst with excellent electrocatalytic performance during ORR in alkaline media, in which nitrogen and boron were embedded into the carbon structure without establishing any bond between $\mathrm{B}$ and $\mathrm{N}$ [200].

\section{Heteroatom Doped Activated Carbon as Electrocatalysts}

Activated carbon (AC) has widely been employed as a main candidate for an electrode material in electrical double-layer capacitance (EDLCs) due to its high porous structure having greater surface area values (1000-3000 $\mathrm{m}^{2} \mathrm{~g}^{-1}$ ) and relatively greater packing density value of $\sim 0.5 \mathrm{~g} \mathrm{~cm}^{-3}$ [201]. In the literature, many research groups synthesized activate carbon materials from bamboo, coconut shell, waste sawdust, etc. [202-205]. The hydrophobic characteristic of AC materials prevented the infiltration of the electrolytes in electrode materials, which further controlled the ion accessible surface area [206]. Moreover, the conductivity value of $\mathrm{sp}^{3}$ type $\mathrm{AC}$ is lesser than that of $\mathrm{sp}^{2}$ carbon, which resulted in lower capacitance [207]. The activated carbon was preferred over CNTs, MOFs, carbides and graphene, as later materials follow complicated, time-consuming and costly methodologies that restrict their large-scale application, regardless of containing higher surface area value with controllable pore structure and having high chemical stability [208]. On the other hand, graphene has very low volumetric capacitance value of less than $40 \mathrm{~F} / \mathrm{cm}^{3}$, in comparison to that of $60 \mathrm{~F} / \mathrm{cm}^{3}$ from activated carbon [209-212]. Chemical doping was an effective way to change the electronic and surface chemical properties of ACs [213]. The incorporation of single, dual or multiple heteroatoms into the carbon structure could enhance its physical and chemical properties to a significant extent [214]. In 2017, Fu et al. reported a highly efficient, low-cost approach to synthesize N-doped porous carbon materials from natural coconut silk fibres via a facile heat treatment and chemical activation. The resulting activated carbon showed excellent catalytic activity and admirable stability for the ORR in alkaline media [215]. Another research group developed the high-performing P-doped activated carbon as a catalyst in air-cathode microbial fuel cells [216]. In this case, phosphorus was present as $\mathrm{C}-\mathrm{O}-\mathrm{P}$ groups, which creates a greater power density value and better electrocatalytic performances [216]. It was reported that AC had shown poor specific capacitance due to having an extensive range of pore size distribution that contradicted with the supercapacitor requirement that pore size should match to the size of electrolyte ions. The hydrophobic nature of ACs resulted in a limitation of ion-accessible surface area due to poor infiltration of electrolyte-to-electrode materials [217]. The optimization was required between pore size, pore structure, surface properties and electrodes' conductivity to enhance maximum capacitance [218]. In this regard, the role of incorporation of nitrogen into ACs was mentioned by Zheng et al. They found a linear relationship between the specific surface area and nitrogen content in functionalized AC towards the capacitance value [219]. Incorporation of heteroatoms in ACs could also be explained through defect mechanism, which was to design defective carbons for ORR [220]. This concept implied that if the desired defect could be produced in AC structure, it could become an active 
electrocatalyst in ORR. In this regard, Yan et al. employed a simple N-doping and removal method, making the inert activated carbon highly active for both the ORR and HER by creating unique defects in the AC [221].

\section{Conclusions}

The heteroatom-doped nanomaterials have drawn huge attention in last two decades in the field of nanoscience and nanotechnology due to their synthetic methodologies, unique properties and potential electrochemical performances through the synergistic effects between the heteroatoms with carbon. The introduction of defects into the carbon-based materials could easily change the distribution of electron density and electronic charge, which could result in remarkable progress in the catalytic performance in various electrochemical reactions. In comparison to the undoped carbon nanomaterials, these specially disordered doped and co-doped materials performed remarkably well as electrocatalysts due to their larger functional surface area value and greater ratio of surface-active groups to volume. This review article covered the most popular potential synthetic methodologies to develop nitrogen, sulphur, phosphorus, boron and their multiple doped, metal-free carbon nanomaterials and discussed elaborately about their electrocatalytic activity in various electrochemical process. The results have clearly shown the enhancement of nanomaterials electrocatalytic activity due to co-doping of multiple heteroatoms into carbon nanostructures, affirmed from the synergistic effect between them. Despite the abundant studies on this topic, many scientific questions are yet to be solved. No such doping methodology has yet been developed that could precisely control the locations of the dopant and its domain sizes. Moreover, it is not clearly understood how the supporting environment interacts with catalytic active centres in these materials. Despite of the challenges, these specially structured nanomaterials exist with many avenues and require more progress in carbon-based nanotechnology with applications in the energy field.

Author Contributions: Conceptualization-D.P.; Writing and editing-J.C. and T.S.P. All authors have read and agreed to the published version of the manuscript.

Funding: This research received no external funding.

Institutional Review Board Statement: Not Applicable.

Informed Consent Statement: Not Applicable.

Data Availability Statement: Not Applicable.

Acknowledgments: This work was supported by Seoul National University of Science and Technology, Korea.

Conflicts of Interest: The authors declare no conflict of interest.

\section{References}

1. Larcher, D.; Tarascon, J.-M. Towards greener and more sustainable batteries for electrical energy storage. Nat. Chem. 2015, 7, 19-29. [CrossRef]

2. Qin, P.; Tanaka, S.; Ito, S.; Tetreault, N.; Manabe, K.; Nishino, H.; Nazeeruddin, M.K.; Graetzel, M. Inorganic hole conductor-based lead halide perovskite solar cells with $12.4 \%$ conversion efficiency. Nat. Commun. 2014, 5, 3834. [CrossRef] [PubMed]

3. Xiong, D.; Li, X.; Bai, Z.; Lu, S. Recent Advances in Layered $\mathrm{Ti}_{3} \mathrm{C}_{2} \mathrm{~T}_{\mathrm{x}} \mathrm{MXene}$ for Electrochemical Energy Storage. Small 2018, 14, e1703419. [CrossRef]

4. Kwak, W.-J.; Rosy; Sharon, D.; Xia, C.; Kim, H.; Johnson, L.R.; Bruce, P.G.; Nazar, L.F.; Sun, Y.-K.; Frimer, A.A.; et al. LithiumOxygen Batteries and Related Systems: Potential, Status, and Future. Chem. Rev. 2020, 120, 6626-6683. [CrossRef] [PubMed]

5. She, Z.W.; Kibsgaard, J.; Dickens, C.F.; Chorkendorff, I.; Nørskov, J.K.; Jaramillo, T.F. Combining theory and experiment in electrocatalysis: Insights into materials design. Science 2017, 355, eaad4998.

6. Shao, M.; Chang, Q.; Dodelet, J.-P.; Chenitz, R. Recent Advances in Electrocatalysts for Oxygen Reduction Reaction. Chem. Rev. 2016, 116, 3594-3657. [CrossRef]

7. Francke, R.; Schille, B.; Roemelt, M. Homogeneously Catalyzed Electroreduction of Carbon Dioxide-Methods, Mechanisms, and Catalysts. Chem. Rev. 2018, 118, 4631-4701. [CrossRef] [PubMed] 
8. Zhu, J.; Hu, L.; Zhao, P.; Lee, L.Y.S.; Wong, K.-Y. Recent Advances in Electrocatalytic Hydrogen Evolution Using Nanoparticles. Chem. Rev. 2020, 120, 851-918. [CrossRef]

9. Suntivich, J.; Gasteiger, H.A.; Yabuuchi, N.; Nakanishi, H.; Goodenough, J.B.; Shao-Horn, Y. Design principles for oxygenreduction activity on perovskite oxide catalysts for fuel cells and metal-air batteries. Nat. Chem. 2011, 3, 546-550. [CrossRef] [PubMed]

10. Fu, S.; Zhu, C.; Song, J.; Du, D.; Lin, Y. Metal-Organic Framework-Derived Non-Precious Metal Nanocatalysts for Oxygen Reduction Reaction. Adv. Energy Mater. 2017, 7, 1700363. [CrossRef]

11. Risch, M. Perovskite Electrocatalysts for the Oxygen Reduction Reaction in Alkaline Media. Catalysts 2017, 7, 154. [CrossRef]

12. Greeley, J.; Stephens, I.E.L.; Bondarenko, A.S.; Johansson, T.P.; Hansen, H.A.; Jaramillo, T.F.; Rossmeisl, J.; Chorkendorff, I.; Norskov, J.K. Alloys of platinum and early transition metals as oxygen reduction electrocatalysts. Nat. Chem. 2009, 1, 552-556. [CrossRef]

13. Cheng, N.; Banis, M.N.; Liu, J.; Riese, A.; Li, X.; Li, R.; Ye, S.; Knights, S.; Sun, X. Extremely Stable Platinum Nanoparticles Encapsulated in a Zirconia Nanocage by Area-Selective Atomic Layer Deposition for the Oxygen Reduction Reaction. Adv. Mater. 2015, 27, 277-281. [CrossRef]

14. Guo, S.; Li, D.; Zhu, H.; Zhang, S.; Marković, N.M.; Stamenkovic, V.R.; Sun, S. FePt and CoPt Nanowires as Efficient Catalysts for the Oxygen Reduction Reaction. Angew. Chem. Int. Ed. 2013, 125, 3549-3552. [CrossRef]

15. Tan, Y.; Xu, C.; Chen, G.; Zheng, N.; Xie, Q. A graphene-platinum nanoparticles-ionic liquid composite catalyst for methanoltolerant oxygen reduction reaction. Energy Environ. Sci. 2012, 5, 6923-6927. [CrossRef]

16. Ávila-García, I.; Plata-Torres, M.; Domínguez-Crespo, M.A.; Ramírez-Rodríguez, C.; Arce-Estrada, E.M. Electrochemical study of $\mathrm{Pt}-\mathrm{Pd}, \mathrm{Pt}-\mathrm{Ru}, \mathrm{Pt}-\mathrm{Rh}$ and $\mathrm{Pt}-\mathrm{Sn} / \mathrm{C}$ in acid media for hydrogen adsorption-desorption reaction. J. Alloys Compd. 2007, 434-435, 764-767. [CrossRef]

17. Hwang, J.T.; Chung, J.S. The morphological and surface properties and their relationship with oxygen reduction activity for platinum-iron electrocatalysts. Electrochim. Acta 1993, 38, 2715-2723. [CrossRef]

18. Kim, H.R.; Chattopadhyay, J.; Son, J.I.; Pak, D. Preparation of platinum-doped hollow spheres and their electrocatalytic activity in water electrolysis. Korean J. Chem. Eng. 2008, 25, 775-779. [CrossRef]

19. Wu, G.; Zelenay, P. Nanostructured Nonprecious Metal Catalysts for Oxygen Reduction Reaction. Acc. Chem. Res. 2013, 46, 1878-1889. [CrossRef] [PubMed]

20. Nouseen, S.; Singh, P.; Lavate, S.; Chattopadhyay, J.; Kuchkaev, A.M.; Yakhvarov, D.G.; Srivastava, R. Transition Metal Based Ternary Hierarchical Metal Sulphide Microspheres as Electrocatalyst for Splitting of Water into Hydrogen and Oxygen Fuel. Catal. Today 2021. [CrossRef]

21. Srivastava, R.; Chattopadhyay, J.; Patel, R.; Agrawal, S.; Nouseen, S.; Kumar, S.; Karmakar, S. Highly efficient ternary hierarchical $\mathrm{NiV}_{2} \mathrm{~S}_{4}$ nanosphere as hydrogen evolving electrocatalyst. Int. J. Hydrog. Energy 2020, 45, 21308-21318. [CrossRef]

22. Behnken, J.; Yu, M.; Deng, X.; Tüysüz, H.; Harms, C.; Dyck, A.; Wittstock, G.; Harun, T. Oxygen Reduction Reaction Activity of Mesostructured Cobalt-Based Metal Oxides Studied with the Cavity-Microelectrode Technique. ChemElectroChem 2019, 6, 3460-3467. [CrossRef]

23. Choi, Y.-J.; Mohamed, H.O.; Park, S.-G.; Al Mayyahi, R.B.; Aldhaifallah, M.; Rezk, H.; Ren, X.; Yu, H.; Chae, K.-J. Electrophoretically fabricated nickel/nickel oxides as cost effective nanocatalysts for the oxygen reduction reaction in air-cathode microbial fuel cell Int. J. Hydrog. Energy 2020, 45, 5960-5970. [CrossRef]

24. Chattopadhyay, J.; Pathak, T.S.; Srivastava, R.; Singh, A.C. Ni Nano-particle Encapsulated in Hollow Carbon Sphere Electrocatalyst in Polymer Electrolyte Membrane Water Electrolyzer. Electrochim. Acta 2015, 167, 429-438. [CrossRef]

25. Peng, H.; Liu, F.; Liu, X.; Liao, S.; You, C.; Tian, X.; Nan, H.; Luo, F.; Song, H.; Fu, Z.; et al. Effect of Transition Metals on the Structure and Performance of the Doped Carbon Catalysts Derived from Polyaniline and Melamine for ORR Application. ACS Catal. 2014, 4, 3797-3805. [CrossRef]

26. Chattopadhyay, J.; Singh, S.; Srivastava, R. Enhanced electrocatalytic performance of Mo-Ni encapsulated in onion-like carbon nano-capsules. J. Appl. Electrochem. 2020, 50, 207-216. [CrossRef]

27. Kumar, S.; Srivastava, R.; Chattopadhyay, J. $\mathrm{M}_{\mathrm{x}} \mathrm{O}_{\mathrm{y}} / \mathrm{M}$ /graphene coated multi-shelled nano-sphere as Bi-functional electrocatalysts for hydrogen and oxygen evolution. Int. J. Hydrog. Energy 2021, 46, 341-356. [CrossRef]

28. Xiong, D.; Li, X.; Fan, L.; Bai, Z. Three-Dimensional Heteroatom-Doped Nanocarbon for Metal-Free Oxygen Reduction Electrocatalysis: A Review. Catalysts 2018, 8, 301. [CrossRef]

29. Sideri, I.K.; Tagmatarchis, N. Noble-Metal-Free Doped Carbon Nanomaterial Electrocatalysts. Chem. A Eur. J. 2020, 26, 15397-15415. [CrossRef]

30. Liu, S.; Yang, H.; Su, X.; Ding, J.; Mao, Q.; Huang, Y.; Zhang, T.; Liu, B. Rational design of carbon-based metal-free catalysts for electrochemical carbon dioxide reduction: A review. J. Energy Chem. 2019, 36, 95-105. [CrossRef]

31. Wang, Y.-J.; Fang, B.; Zhang, D.; Li, A.; Wilkinson, D.P.; Ignaszak, A.; Zhang, L.; Zhang, J. A Review of Carbon-Composited Materials as Air-Electrode Bifunctional Electrocatalysts for Metal-Air Batteries. Electrochem. Energy Rev. 2018, 1, 1-34. [CrossRef]

32. Liu, X.; Dai, L. Carbon-based metal-free catalysts. Nat. Rev. Mater. 2016, 1, 16064. [CrossRef]

33. Sawant, S.Y.; Han, T.H.; Cho, M.H. Metal-Free Carbon-Based Materials: Promising Electrocatalysts for Oxygen Reduction Reaction in Microbial Fuel Cells. Int J Mol Sci. 2017, 18, 25. [CrossRef] 
34. Lin, Z.; Waller, G.; Liu, Y.; Liu, M.; Wong, C.-P. Facile Synthesis of Nitrogen-Doped Graphene via Pyrolysis of Graphene Oxide and Urea, and its Electrocatalytic Activity toward the Oxygen-Reduction Reaction. Adv. Energy Mater. 2012, 2, 884-888. [CrossRef]

35. Wang, H.; Jia, J.; Song, P.; Wang, Q.; Li, D.; Min, S.; Qian, C.; Wang, L.; Li, Y.F.; Ma, C.; et al. Efficient Electrocatalytic Reduction of $\mathrm{CO}_{2}$ by Nitrogen-Doped Nanoporous Carbon/Carbon Nanotube Membranes: A Step Towards the Electrochemical $\mathrm{CO}_{2}$ Refinery. Angew. Chem. Int. Ed. 2017, 56, 7847-7852. [CrossRef]

36. Stergiou, A.; Cantón-Vitoria, R.; Psarrou, M.N.; Economopoulos, S.; Tagmatarchis, N. Functionalized graphene and targeted applications-Highlighting the road from chemistry to applications. Prog. Mater. Sci. 2020, 114, 100683. [CrossRef]

37. Karousis, N.; Tagmatarchis, N.; Tasis, D. Current Progress on the Chemical Modification of Carbon Nanotubes. Chem. Rev. 2010, 110, 5366-5397. [CrossRef]

38. Tasis, D.; Tagmatarchis, N.; Bianco, A.; Prato, M. Chemistry of Carbon Nanotubes. Chem. Rev. 2006, 106, 1105-1136. [CrossRef] [PubMed]

39. Karousis, N.; Suarez-Martinez, I.; Ewels, C.P.; Tagmatarchis, N. Structure, Properties, Functionalization, and Applications of Carbon Nanohorns. Chem. Rev. 2016, 116, 4850-4883. [CrossRef]

40. Jana, D.; Sun, C.-L.; Chen, L.-C.; Chen, K.-H. Effect of chemical doping of boron and nitrogen on the electronic, optical, and electrochemical properties of carbon nanotubes. Prog. Mater. Sci. 2013, 58, 565-635. [CrossRef]

41. Sumpter, B.G.; Huang, J.; Meunier, V.; Romo-Herrera, J.M.; Cruz-Silva, E.; Terrones, H.; Terrones, M. A theoretical and experimental study on manipulating the structure and properties of carbon nanotubes using substitutional dopants. Int. J. Quantum Chem. 2009, 109, 97-118. [CrossRef]

42. Ekimov, E.A.; Sidorov, V.A.; Bauer, E.D.; Mel'Nik, N.N.; Curro, N.; Thompson, J.D.; Stishov, S.M. Superconductivity in diamond. Nature 2004, 428, 542-545. [CrossRef] [PubMed]

43. Czerw, R.; Terrones, M.; Charlier, J.-C.; Blase, X.; Foley, B.; Kamalakaran, R.; Grobert, N.; Terrones, H.; Tekleab, D.; Ajayan, P.M.; et al. Identification of Electron Donor States in N-Doped Carbon Nanotubes. Nano Lett. 2001, 1, 457-460. [CrossRef]

44. Cruz-Silva, E.; Cullen, D.A.; Gu, L.; Romo-Herrera, J.M.; Muñoz-Sandoval, E.; López-Urías, F.; Sumpter, B.G.; Meunier, V.; Charlier, J.-C.; Smith, D.J.; et al. Heterodoped Nanotubes: Theory, Synthesis, and Characterization of Phosphorus-Nitrogen Doped Multiwalled Carbon Nanotubes. ACS Nano 2008, 2, 441-448. [CrossRef]

45. Fan, Q.; Noh, H.-J.; Wei, Z.; Zhang, J.; Lian, X.; Ma, J.; Jung, S.-M.; Jeon, I.-Y.; Xu, J.; Baek, J.-B. Edge-thionic acid-functionalized graphene nanoplatelets as anode materials for high-rate lithium ion batteries. Nano Energy 2019, 62, 419-425. [CrossRef]

46. Jeon, I.-Y.; Ju, M.J.; Xu, J.; Choi, H.-J.; Seo, J.-M.; Kim, M.-J.; Choi, I.T.; Kim, H.M.; Kim, J.C.; Lee, J.-J.; et al. Edge-Fluorinated Graphene Nanoplatelets as High Performance Electrodes for Dye-Sensitized Solar Cells and Lithium Ion Batteries. Adv. Funct. Mater. 2015, 25, 1170-1179. [CrossRef]

47. Jeon, I.-Y.; Choi, H.-J.; Ju, M.J.; Choi, I.T.; Lim, K.; Ko, J.; Kim, H.K.; Kim, J.C.; Lee, J.-J.; Shin, D.; et al. Direct nitrogen fixation at the edges of graphene nanoplatelets as efficient electrocatalysts for energy conversion. Sci. Rep. 2013, 3, 2260. [CrossRef]

48. Ju, M.J.; Jeon, I.-Y.; Kim, H.M.; Choi, J.I.; Jung, S.-M.; Seo, J.-M.; Choi, I.T.; Kang, S.H.; Kim, H.S.; Noh, M.J.; et al. Edge-selenated graphene nanoplatelets as durable metal-free catalysts for iodine reduction reaction in dye-sensitized solar cells. Sci. Adv. 2016, 2, e1501459. [CrossRef]

49. Jeon, I.-Y.; Kim, H.M.; Kweon, D.H.; Jung, S.-M.; Seo, J.-M.; Shin, S.-H.; Choi, I.T.; Eom, Y.K.; Kang, S.H.; Kim, H.K.; et al. Metalloid tellurium-doped graphene nanoplatelets as ultimately stable electrocatalysts for cobalt reduction reaction in dye-sensitized solar cells. Nano Energy 2016, 30, 867-876. [CrossRef]

50. Chen, Z.; Higgins, D.; Tao, H.; Hsu, R.S.; Chen, Z. Highly Active Nitrogen-Doped Carbon Nanotubes for Oxygen Reduction Reaction in Fuel Cell Applications. J. Phys. Chem. C 2009, 113, 21008-21013. [CrossRef]

51. Qu, L.; Liu, Y.; Baek, J.-B.; Dai, L. Nitrogen-Doped Graphene as Efficient Metal-Free Electrocatalyst for Oxygen Reduction in Fuel Cells. ACS Nano 2010, 4, 1321-1326. [CrossRef]

52. Feng, L.; Yan, Y.; Chen, Y.; Wang, L. Nitrogen-doped carbon nanotubes as efficient and durable metal-free cathodic catalysts for oxygen reduction in microbial fuel cells. Energy Environ. Sci. 2011, 4, 1892-1899. [CrossRef]

53. Liao, L.; Pan, C. Enhanced Electrochemical Capacitance of Nitrogen-Doped Carbon Nanotubes Synthesized from Amine Flames. Soft Nanosci. Lett. 2011, 1, 16-23. [CrossRef]

54. O’Byrne, J.P.; Li, Z.; Jones, S.L.T.; Fleming, P.G.; Larsson, J.A.; Morris, M.A.; Holmes, J.D. Nitrogen-Doped Carbon Nanotubes: Growth, Mechanism and Structure. ChemPhysChem 2011, 12, 2995-3001. [CrossRef] [PubMed]

55. Xue, Y.; Liu, J.; Chen, H.; Wang, R.; Li, D.; Qu, J.; Dai, L. Nitrogen-Doped Graphene Foams as Metal-Free Counter Electrodes in High-Performance Dye-Sensitized Solar Cells. Angew. Chem. Int. Ed. 2012, 51, 12124-12127. [CrossRef]

56. Li, Q.; Zhang, S.; Dai, L.; Li, L.-S. Nitrogen-Doped Colloidal Graphene Quantum Dots and Their Size-Dependent Electrocatalytic Activity for the Oxygen Reduction Reaction. J. Am. Chem. Soc. 2012, 134, 18932-18935. [CrossRef]

57. Zhao, Y.; Nakamura, R.; Kamiya, K.; Nakanishi, S.; Hashimoto, K. Nitrogen-doped carbon nanomaterials as non-metal electrocatalysts for water oxidation. Nat. Commun. 2013, 4, 2390. [CrossRef] [PubMed]

58. Zheng, Y.; Jiao, Y.; Zhu, Y.; Li, L.; Han, Y.; Chen, Y.; Du, A.; Jaroniec, M.; Qiao, S.Z. Hydrogen evolution by a metal-free electrocatalyst. Nat. Commun. 2014, 5, 3783. [CrossRef]

59. Shui, J.; Wang, M.; Du, F.; Dai, L. N-doped carbon nanomaterials are durable catalysts for oxygen reduction reaction in acidic fuel cells. Sci. Adv. 2015, 1, e1400129. [CrossRef] [PubMed] 
60. Zhang, J.; Zhao, Z.; Xia, Z.; Dai, L. A metal-free bifunctional electrocatalyst for oxygen reduction and oxygen evolution reactions. Nat. Nanotechnol. 2015, 10, 444-452. [CrossRef]

61. Jiang, Y.; Yang, L.; Sun, T.; Zhao, J.; Lyu, Z.; Zhuo, O.; Wang, X.; Wu, Q.; Ma, J.; Hu, Z. Significant Contribution of Intrinsic Carbon Defects to Oxygen Reduction Activity. ACS Catal. 2015, 5, 6707-6712. [CrossRef]

62. Zhang, J.; Qu, L.; Shi, G.; Liu, J.; Chen, J.; Dai, L. N,P-Codoped Carbon Networks as Efficient Metal-free Bifunctional Catalysts for Oxygen Reduction and Hydrogen Evolution Reactions. Angew. Chem. Int. Ed. 2016, 55, 2230-2234. [CrossRef] [PubMed]

63. Hu, C.; Dai, L. Multifunctional Carbon-Based Metal-Free Electrocatalysts for Simultaneous Oxygen Reduction, Oxygen Evolution, and Hydrogen Evolution. Adv. Mater. 2017, 29, 1604942. [CrossRef] [PubMed]

64. Liu, L.; Zeng, G.; Chen, J.; Bi, L.; Dai, L.; Wen, Z. N-doped porous carbon nanosheets as pH-universal ORR electrocatalyst in various fuel cell devices. Nano Energy 2018, 49, 393-402. [CrossRef]

65. Liu, Y.; Su, Y.; Quan, X.; Fan, X.; Chen, S.; Yu, H.; Zhao, H.; Zhang, Y.; Zhao, J. Facile Ammonia Synthesis from Electrocatalytic N2 Reduction under Ambient Conditions on N-Doped Porous Carbon. ACS Catal. 2018, 8, 1186-1191. [CrossRef]

66. Mukherjee, S.; Cullen, D.A.; Karakalos, S.; Liu, K.; Zhang, H.; Zhao, S.; Xu, H.; More, K.L.; Wang, G.; Wu, G. Metal-organic framework-derived nitrogen-doped highly disordered carbon for electrochemical ammonia synthesis using $\mathrm{N}_{2}$ and $\mathrm{H}_{2} \mathrm{O}$ in alkaline electrolytes. Nano Energy 2018, 48, 217-226. [CrossRef]

67. Jia, Y.; Zhang, L.; Zhuang, L.; Liu, H.; Yan, X.; Wang, X.; Liu, J.; Wang, J.; Zheng, Y.; Xiao, Z.; et al. Identification of active sites for acidic oxygen reduction on carbon catalysts with and without nitrogen doping. Nat. Catal. 2019, 2, 688-695. [CrossRef]

68. Kim, C.K.; Ji, J.-M.; Zhou, H.; Lu, C.; Kim, H.K. Tellurium-Doped, Mesoporous Carbon Nanomaterials as Transparent Metal-Free Counter Electrodes for High-Performance Bifacial Dye-Sensitized Solar Cells. Nanomaterials 2020, 10, 29. [CrossRef]

69. Zong, L.; Wu, W.; Liu, S.; Yin, H.; Chen, Y.; Liu, C.; Fan, K.; Zhao, X.; Chen, X.; Wang, F.; et al. Metal-free, active nitrogen-enriched, efficient bifunctional oxygen electrocatalyst for ultrastable zinc-air batteries. Energy Storage Mater. 2020, 27, 514-521. [CrossRef]

70. Liang, S.; Liu, F.; Jiang, L. Recent advances on nitrogen-doped metal-free materials for the selective catalytic oxidation of hydrogen sulfide. Curr. Opin. Green Sustain. Chem. 2020, 25, 100361. [CrossRef]

71. Saka, C. Oxygen and nitrogen-doped metal-free microalgae carbon nanoparticles for efficient hydrogen production from sodium borohydride in methanol. Int. J. Hydrog. Energy 2021, 46, 26298-26307. [CrossRef]

72. Zhao, R.; Chen, Y.; Huang, S. Doping engineering on carbons as electrocatalysts for oxygen reduction reaction. Fund. Res. 2021, 1, 807-823. [CrossRef]

73. Ahmad, S.; Guillén, E.; Kavan, L.; Grätzel, M.; Nazeeruddin, M.K. Metal free sensitizer and catalyst for dye sensitized solar cells. Energy Environ. Sci. 2013, 6, 3439-3466. [CrossRef]

74. Choi, H.C.; Park, J.; Kim, B. Distribution and Structure of N Atoms in Multiwalled Carbon Nanotubes Using Variable-Energy X-Ray Photoelectron Spectroscopy. J. Phys. Chem. B 2005, 109, 4333-4340. [CrossRef] [PubMed]

75. Hu, J.; Yang, P.; Lieber, C.M. Nitrogen-driven $\mathrm{sp}^{3}$ to $\mathrm{sp}^{2}$ transformation in carbon nitride materials. Phys. Rev. B 1998, 57, R3185. [CrossRef]

76. Ayala, P.; Arenal, R.; Rümmeli, M.H.; Rubio, A.; Pichler, T. The doping of carbon nanotubes with nitrogen and their potential applications. Carbon 2010, 48, 575-586. [CrossRef]

77. Yang, J.; Liu, D.-J.; Kariuki, N.N.; Chen, L.X. Aligned carbon nanotubes with built-in FeN $\mathrm{N}_{4}$ active sites for electrocatalytic reduction of oxygen. Chem. Commun. 2008, 3, 329-331. [CrossRef]

78. Lee, D.H.; Lee, W.J.; Kim, S.O. Highly Efficient Vertical Growth of Wall-Number-Selected, N-Doped Carbon Nanotube Arrays. Nano Lett. 2009, 9, 1427-1432. [CrossRef] [PubMed]

79. Ramanathan, T.; Fisher, F.T.; Ruoff, R.S.; Brinson, L.C. Amino-Functionalized Carbon Nanotubes for Binding to Polymers and Biological Systems. Chem. Mater. 2005, 17, 1290-1295. [CrossRef]

80. Li, J.; Vergne, M.J.; Mowles, E.D.; Zhong, W.-H.; Hercules, D.M.; Lukehart, C.M. Surface functionalization and characterization of graphitic carbon nanofibers (GCNFs). Carbon 2005, 43, 2883-2893. [CrossRef]

81. Tang, C.; Bando, Y.; Golberg, D.; Xu, F. Structure and nitrogen incorporation of carbon nanotubes synthesized by catalytic pyrolysis of dimethylformamide. Carbon 2004, 42, 2625-2633. [CrossRef]

82. Stephan, O.; Ajayan, P.M.; Colliex, C.; Redlich, P.; Lambert, J.M.; Bernier, P.; Lefin, P. Doping Graphitic and Carbon Nanotube Structures with Boron and Nitrogen. Science 1994, 266, 1683-1685. [CrossRef]

83. Droppa, R., Jr.; Hammer, P.; Carvalho, A.C.M.; dos Santos, M.C.; Alvarez, F. Incorporation of nitrogen in carbon nanotubes. J. Non-Cryst. Solids 2002, 299-302, 874-879. [CrossRef]

84. Hu, J.; Yang, P.; Lieber, C.M. Nitrogen driven structural transformation in carbon nitride materials. Appl. Surf. Sci. 1998, 127-129, 569-573. [CrossRef]

85. Rodil, S.E.; Milne, W.I.; Robertson, J.; Brown, L.M. Maximized sp ${ }^{3}$ bonding in carbon nitride phases. Appl. Phys. Lett. 2000, 77, 1458-1460. [CrossRef]

86. Yu, D.; Zhang, Q.; Dai, L. Highly Efficient Metal-Free Growth of Nitrogen-Doped Single-Walled Carbon Nanotubes on PlasmaEtched Substrates for Oxygen Reduction. J. Am. Chem. Soc. 2010, 132, 15127-15129. [CrossRef] [PubMed]

87. Luais, E.; Thobie-Gautier, C.; Tailleur, A.; Djouadi, M.-A.; Granier, A.; Tessier, P.Y.; Debarnot, D.; Poncin-Epaillard, F.; Boujtita, M. Preparation and modification of carbon nanotubes electrodes by cold plasmas processes toward the preparation of amperometric biosensors. Electrochim. Acta 2010, 55, 7916-7922. [CrossRef]

88. Iijima, S. Helical microtubules of graphitic carbon. Nature 1991, 354, 56-58. [CrossRef] 
89. Majeed, S.; Zhao, J.; Zhang, L.; Anjum, S.; Liu, Z.; Xu, G. Synthesis and electrochemical applications of nitrogen-doped carbon nanomaterials. Nanotechnol. Rev. 2013, 2, 615-635. [CrossRef]

90. Ning, X.; Li, Y.; Dong, B.; Wang, H.; Yu, H.; Peng, F.; Yang, Y. Electron transfer dependent catalysis of Pt on N-doped carbon nanotubes: Effects of synthesis method on metal-support interaction. J. Catalysis. 2017, 348, 100-109. [CrossRef]

91. Terrones, M.; Grobert, N.; Terrones, H. Synthetic routes to nanoscale $\mathrm{B}_{\mathrm{x}} \mathrm{C}_{\mathrm{y}} \mathrm{N}_{\mathrm{z}}$ architectures. Carbon 2002, 40, 1665-1684. [CrossRef]

92. Ewels, C.P.; Glerup, M. Nitrogen Doping in Carbon Nanotubes. J. Nanosci. Nanotechnol. 2005, 5, 1345-1363. [CrossRef]

93. Villalpando-Páez, F.; Romero, A.H.; Muñoz-Sandoval, E.; Martínez, L.M.; Terrones, H.; Terrones, M. Fabrication of vapor and gas sensors using films of aligned $\mathrm{CN}_{\mathrm{x}}$ nanotubes. Chem. Phys. Lett. 2004, 386, 137-143. [CrossRef]

94. Doytcheva, M.; Kaiser, M.; Verheijen, M.A.; Reyes-Reyes, M.; Terrones, M.; de Jonge, N. Electron emission from individual nitrogen-doped multi-walled carbon nanotubes. Chem. Phys. Lett. 2004, 396, 126-130. [CrossRef]

95. Zhang, J.; Cheng, F.-F.; Zheng, T.-T.; Zhu, J.-J. Design and Implementation of Electrochemical Cytosensor for Evaluation of Cell Surface Carbohydrate and Glycoprotein. Anal. Chem. 2010, 82, 3547-3555. [CrossRef] [PubMed]

96. Souza, A.M.; Rocha, A.R.; Fazzio, A.; da Silva, A.J.R. Ab-initio calculations for a realistic sensor: A study of CO sensors based on nitrogen-rich carbon nanotubes. AIP Adv. 2012, 2, 032115. [CrossRef]

97. Terrones, M.; Kamalakaran, R.; Seeger, T.; Rühle, M. Novel nanoscale gas containers: Encapsulation of $\mathrm{N}_{2}$ in $\mathrm{CN}_{\mathrm{x}}$ nanotubes. Chem. Commun. 2000, 23, 2335-2336. [CrossRef]

98. Peng, Q.; He, X.; Li, Y.; Wang, C.; Wang, R.; Hu, P.; Yan, Y.; Sritharan, T. Chemically and uniformly grafting carbon nanotubes onto carbon fibers by poly(amidoamine) for enhancing interfacial strength in carbon fiber composites. J. Mater. Chem. 2012, 22, 5928-5931. [CrossRef]

99. Jiang, K.; Eitan, A.; Schadler, L.S.; Ajayan, P.M.; Siegel, R.W.; Grobert, N.; Mayne, M.; Reyes-Reyes, M.; Terrones, H.; Terrones, M. Selective Attachment of Gold Nanoparticles to Nitrogen-Doped Carbon Nanotubes. Nano Lett. 2003, 3, 275-277. [CrossRef]

100. Kim, K.K.; Kim, D.; Kim, S.K.; Park, S.M.; Song, J.K. Formation of ZnO nanoparticles by laser ablation in neat water. Chem. Phys. Lett. 2011, 511, 116-120. [CrossRef]

101. Iijima, S.; Ichihashi, T. Single-shell carbon nanotubes of 1-nm diameter. Nature 1993, 363, 603-605. [CrossRef]

102. Takenobu, T.; Takano, T.; Shiraishi, M.; Murakami, Y.; Ata, M.; Kataura, H.; Achiba, Y.; Iwasa, Y. Stable and controlled amphoteric doping by encapsulation of organic molecules inside carbon nanotubes. Nat. Mater. 2003, 2, 683-688. [CrossRef] [PubMed]

103. Terrones, M. Carbon nanotubes: Synthesis and properties, electronic devices and other emerging applications. Int. Mater. Rev. 2004, 49, 325-377. [CrossRef]

104. Dai, L.; Griesser, H.J.; Mau, A.W.H. Surface Modification by Plasma Etching and Plasma Patterning. J. Phys. Chem. B 1997, 101, 9548-9554. [CrossRef]

105. Chen, Z.; Higgins, D.; Chen, Z. Electrocatalytic activity of nitrogen doped carbon nanotubes with different morphologies for oxygen reduction reaction. Electrochim. Acta 2010, 55, 4799-4804. [CrossRef]

106. Nxumalo, E.N.; Nyamori, V.O.; Coville, N.J. CVD synthesis of nitrogen doped carbon nanotubes using ferrocene/aniline mixtures. J. Organomet. Chem. 2008, 693, 2942-2948. [CrossRef]

107. Yang, Z.; Xia, Y.; Mokaya, R. Aligned N-Doped Carbon Nanotube Bundles Prepared via CVD Using Zeolite Substrates. Chem. Mater. 2005, 17, 4502-4508. [CrossRef]

108. He, M.; Zhou, S.; Zhang, J.; Liu, Z.; Robinson, C. CVD Growth of N-Doped Carbon Nanotubes on Silicon Substrates and Its Mechanism. J. Phys. Chem. B 2005, 109, 9275-9279. [CrossRef]

109. Kim, S.Y.; Lee, J.; Na, C.W.; Park, J.; Seo, K.; Kim, B. N-doped double-walled carbon nanotubes synthesized by chemical vapor deposition. Chem. Phys. Lett. 2005, 413, 300-305. [CrossRef]

110. Li, H.-F.; Wu, F.; Wang, C.; Zhang, P.-X.; Hu, H.-Y.; Xie, N.; Pan, M.; Zeng, Z.; Deng, S.; Wu, M.H.; et al. One-Step Chemical Vapor Deposition Synthesis of 3D N-doped Carbon Nanotube/N-doped Graphene Hybrid Material on Nickel Foam. Nanomaterials 2018, 8, 700. [CrossRef]

111. Maślana, K.; Kaleńczuk, R.J.; Zielińska, B.; Mijowska, E. Synthesis and Characterization of Nitrogen-doped Carbon Nanotubes Derived from $\mathrm{g}-\mathrm{C}_{3} \mathrm{~N}_{4}$. Materials 2020, 13, 1349. [CrossRef] [PubMed]

112. Xu, Z.; Li, H.; Fu, M.; Luo, H.; Sun, H.; Zhang, L.; Li, K.; Wei, B.; Lu, J.; Zhao, X. Nitrogen-doped carbon nanotubes synthesized by pyrolysis of nitrogen-rich metal phthalocyanine derivatives for oxygen reduction. J. Mater. Chem. 2012, 22, 18230-18236. [CrossRef]

113. Gulino, G.; Vieira, R.; Amadou, J.; Nguyen, P.; Ledoux, M.J.; Galvagno, S.; Centi, G.; Cuong, P.H. Synthesis of carbon nanotubes by chemical vapour deposition. Appl. Catal. A Gen. 2005, 279, 89-97. [CrossRef]

114. Dong, J.; Qu, X.; Wang, L.; Zhao, C.; Xu, J. Electrochemistry of Nitrogen-Doped Carbon Nanotubes $\left(\mathrm{CN}_{\mathrm{X}}\right)$ with Different Nitrogen Content and Its Application in Simultaneous Determination of Dihydroxybenzene Isomers. Electroanalysis 2008, 20, 1981-1986. [CrossRef]

115. Liu, H.; Zhang, Y.; Li, R.; Sun, X.; Désilets, S.; Abou-Rachid, H.; Jaidann, M.; Lussier, L.-S. Structural and morphological control of aligned nitrogen-doped carbon nanotubes. Carbon 2010, 48, 1498-1507. [CrossRef]

116. Wang, Z.; Jia, R.; Zheng, J.; Zhao, J.; Li, L.; Song, J.; Zhu, Z. Nitrogen-Promoted Self-Assembly of N-Doped Carbon Nanotubes and Their Intrinsic Catalysis for Oxygen Reduction in Fuel Cells. ACS Nano 2011, 5, 1677-1684. [CrossRef]

117. Xu, E.; Wei, J.; Wang, K.; Li, Z.; Gui, X.; Jia, Y.; Zhu, H.; Wu, D. Doped carbon nanotube array with a gradient of nitrogen concentration. Carbon 2010, 48, 3097-3102. [CrossRef] 
118. Abuilaiwi, F.A.; Laoui, T.; Al-Harthi, M.; Atieh, M.A. Modification and functionalization of multiwalled carbon nanotube (MWCNT) via Fischer esterification. Arab. J. Sci. Eng. 2010, 35, 37-48.

119. Jiang, K.; Schadler, L.S.; Siegel, R.W.; Zhang, X.; Zhang, H.; Terrones, M. Protein immobilization on carbon nanotubes via a two-step process of diimide-activated amidation. J. Mater. Chem. 2004, 14, 37-39. [CrossRef]

120. Ambrogi, V.; Gentile, G.; Ducati, C.; Oliva, M.C.; Carfagna, C. Multiwalled carbon nanotubes functionalized with maleated poly(propylene) by a dry mechano-chemical process. Polymer 2012, 53, 291-299. [CrossRef]

121. Chen, L.; Xie, H.; Li, Y.; Yu, W. Surface Chemical Modification of Multiwalled Carbon Nanotubes by a Wet-Mechanochemical Reaction. J. Nanomater. 2008, 2008, 783981. [CrossRef]

122. Fechler, N.; Fellinger, T.-P.; Antonietti, M. Template-Free One-Pot Synthesis of Porous Binary and Ternary Metal Nitride@N-Doped Carbon Composites from Ionic Liquids. Chem. Mater. 2012, 24, 713-719. [CrossRef]

123. Pan, C.; Qiu, L.; Peng, Y.; Yan, F. Facile synthesis of nitrogen-doped carbon-Pt nanoparticle hybrids via carbonization of poly([Bvim][Br]-co-acrylonitrile) for electrocatalytic oxidation of methanol. J. Mater. Chem. 2012, 22, 13578-13584. [CrossRef]

124. Fan, L.; Chen, J.; Zhu, S.; Wang, M.; Xu, G. Determination of $\mathrm{Cd}^{2+}$ and $\mathrm{Pb}^{2+}$ on glassy carbon electrode modified by electrochemical reduction of aromatic diazonium salts. Electrochem. Commun. 2009, 11, 1823-1825. [CrossRef]

125. Wu, H.-X.; Tong, R.; Qiu, X.-Q.; Yang, H.-F.; Lin, Y.-H.; Cai, R.-F.; Qian, S.-X. Functionalization of multiwalled carbon nanotubes with polystyrene under atom transfer radical polymerization conditions. Carbon 2007, 45, 152-159. [CrossRef]

126. Maiyalagan, T. Synthesis and electro-catalytic activity of methanol oxidation on nitrogen containing carbon nanotubes supported Pt electrodes. Appl. Catal. B: Environ. 2008, 80, 286-295. [CrossRef]

127. Wei, W.; Li, P.; Li, Y.; Cao, X.; Liu, S. Nitrogen-doped carbon nanotubes enhanced laccase enzymatic reactivity towards oxygen reduction and its application in biofuel cell. Electrochem. Commun. 2012, 22, 181-184. [CrossRef]

128. Kooi, S.E.; Schlecht, U.; Burghard, M.; Kern, K. Electrochemical Modification of Single Carbon Nanotubes. Angew. Chem. Int. Ed. 2002, 41, 1353-1355. [CrossRef]

129. Tu, W.; Lei, J.; Jian, G.; Hu, Z.; Ju, H. Noncovalent Assembly of Picket-Fence Porphyrins on Nitrogen-Doped Carbon Nanotubes for Highly Efficient Catalysis and Biosensing. Chemistry 2010, 16, 4120-4126. [CrossRef]

130. Zhu, J.; Zhou, H.; Zhang, C.; Zhang, J.; Mu, S. Dual active nitrogen doped hierarchical porous hollow carbon nanospheres as an oxygen reduction electrocatalyst for zinc-air batteries. Nanoscale 2017, 9, 13257-13263. [CrossRef] [PubMed]

131. Gu, D.; Ma, R.; Zhou, Y.; Wang, F.; Yan, K.; Liu, Q.; Wang, J. Synthesis of Nitrogen-Doped Porous Carbon Spheres with Improved Porosity toward the Electrocatalytic Oxygen Reduction. ACS Sustain. Chem. Eng. 2017, 5, 11105-11116. [CrossRef]

132. Zhang, H.; Chen, J.; Li, Y.; Liu, P.; Wang, Y.; An, T.; Zhao, H. Nitrogen-Doped Carbon Nanodots@Nanospheres as An Efficient Electrocatalyst for Oxygen Reduction Reaction. Electrochim. Acta 2015, 165, 7-13. [CrossRef]

133. Wu, L.; Shen, Y.; Yu, L.; Xi, J.; Qiu, X. Boosting vanadium flow battery performance by Nitrogen-doped carbon nanospheres electrocatalyst. Nano Energy 2016, 28, 19-28. [CrossRef]

134. Wang, M.; Peng, F.; Wang, M.; Han, J. N-Doped carbon nanospheres with nanocavities to encapsulate manganese oxides as ORR electrocatalysts. New J. Chem. 2020, 44, 14915-14921. [CrossRef]

135. Wu, X.; Niu, Y.; Feng, B.; Yu, Y.; Huang, X.; Zhong, C.; Hu, W.; Li, C.M. Mesoporous Hollow Nitrogen-Doped Carbon Nanospheres with Embedded $\mathrm{MnFe}_{2} \mathrm{O}_{4} / \mathrm{Fe}$ Hybrid Nanoparticles as Efficient Bifunctional Oxygen Electrocatalysts in Alkaline Media. ACS Appl. Mater. Interfaces 2018, 10, 20440-20447. [CrossRef]

136. Zhang, K.; Zhang, L.; Chen, X.; He, X.; Wang, X.; Dong, S.; Gu, L.; Liu, Z.; Huang, C.; Cui, G. Molybdenum Nitride/N-Doped Carbon Nanospheres for Lithium- $\mathrm{O}_{2}$ Battery Cathode Electrocatalyst. ACS Appl. Mater. Interfaces 2013, 5, 3677-3682. [CrossRef]

137. Chen, Y.; Li, Z.; Zhu, Y.; Sun, D.; Liu, X.; Xu, L.; Tang, Y. Atomic Fe Dispersed on N-Doped Carbon Hollow Nanospheres for High-Efficiency Electrocatalytic Oxygen Reduction. Adv. Mater. 2019, 31, e1806312. [CrossRef]

138. Feng, Q.; Xiong, Y.; Xie, L.; Zhang, Z.; Lu, X.; Wang, Y.; Yuan, X.-Z.; Fan, J.; Li, H.; Wang, H. Tungsten Carbide Encapsulated in Grape-Like N-Doped Carbon Nanospheres: One-Step Facile Synthesis for Low-Cost and Highly Active Electrocatalysts in Proton Exchange Membrane Water Electrolyzers. ACS Appl. Mater. Interfaces 2019, 11, 25123-25132. [CrossRef]

139. Zhu, J.; Abdelkader, A.; Demko, D.; Deng, L.; Zhang, P.; He, T.; Wang, Y.; Huang, L. Electrocatalytic Assisted Performance Enhancement for the Na-S Battery in Nitrogen-Doped Carbon Nanospheres Loaded with Fe. Molecules 2020, 25, 1585. [CrossRef] [PubMed]

140. Chi, J.-Q.; Gao, W.-K.; Zhang, L.-M.; Dong, B.; Yan, K.-L.; Lin, J.-H.; Liu, B.; Chai, Y.-M.; Liu, C.-G. Induced PhosphorizationDerived Well-Dispersed Molybdenum Phosphide Nanoparticles Encapsulated in Hollow N-Doped Carbon Nanospheres for Efficient Hydrogen Evolution. ACS Sustain. Chem. Eng. 2018, 6, 7676-7686. [CrossRef]

141. Gavrilov, N.; Pašti, I.A.; Vujković, M.; Travas-Sejdic, J.; Ćirić-Marjanović, G.; Mentus, S.V. High-performance charge storage by $\mathrm{N}$-containing nanostructured carbon derived from polyaniline. Carbon 2012, 50, 3915-3927. [CrossRef]

142. Geim, A.K.; Novoselov, K.S. The rise of graphene. Nat. Mater. 2007, 6, 183-191. [CrossRef] [PubMed]

143. Hass, J.; de Heer, W.A.; Conrad, E.H. The growth and morphology of epitaxial multilayer graphene. J. Phys. Cond. Matt. 2008, 20, 323202. [CrossRef]

144. Wang, C.; Zhou, Y.; He, L.; Ng, T.; Hong, G.; Wu, Q.-H.; Gao, F.; Lee, C.-S.; Zhang, W. In situ nitrogen-doped graphene grown from polydimethylsiloxane by plasma enhanced chemical vapor deposition. Nanoscale 2013, 5, 600-605. [CrossRef]

145. Gao, Y.; Hu, G.; Zhong, J.; Shi, Z.; Zhu, Y.; Su, D.S.; Wang, J.; Bao, X.; Ma, D. Nitrogen-Doped sp ${ }^{2}$-Hybridized Carbon as a Superior Catalyst for Selective Oxidation. Angew. Chem. Int. Ed. 2013, 52, 2109-2113. [CrossRef] 
146. Jeong, H.M.; Lee, S.Y.; Shin, W.H.; Kwon, J.H.; Shakoor, A.; Hwang, T.H.; Kim, S.Y.; Kong, B.-S.; Seo, J.-S.; Lee, Y.M.; et al. Silicon@porous nitrogen-doped carbon spheres through a bottom-up approach are highly robust lithium-ion battery anodes. RSC Adv. 2012, 2, 4311-4317. [CrossRef]

147. Li, Y.; Zhao, Y.; Cheng, H.; Hu, Y.; Shi, G.; Dai, L.; Qu, L. Nitrogen-Doped Graphene Quantum Dots with Oxygen-Rich Functional Groups. J. Am. Chem. Soc. 2012, 134, 15-18. [CrossRef]

148. Jeong, H.M.; Lee, J.W.; Shin, W.H.; Choi, Y.J.; Shin, H.J.; Kang, J.K.; Choi, J.W. Nitrogen-Doped Graphene for High-Performance Ultracapacitors and the Importance of Nitrogen-Doped Sites at Basal Planes. Nano Lett. 2011, 11, 2472-2477. [CrossRef]

149. Jin, Z.; Yao, J.; Kittrell, C.; Tour, J.M. Large-Scale Growth and Characterizations of Nitrogen-Doped Monolayer Graphene Sheets. ACS Nano 2011, 5, 4112-4117. [CrossRef]

150. Wei, D.; Liu, Y.; Wang, Y.; Zhang, H.; Huang, L.; Yu, G. Synthesis of N-Doped Graphene by Chemical Vapor Deposition and Its Electrical Properties. Nano Lett. 2009, 9, 1752-1758. [CrossRef] [PubMed]

151. Wang, Y.; Shao, Y.; Matson, D.W.; Li, J.; Lin, Y. Nitrogen-Doped Graphene and Its Application in Electrochemical Biosensing. ACS Nano 2010, 4, 1790-1798. [CrossRef]

152. Zhang, C.; Fu, L.; Liu, N.; Liu, M.; Wang, Y.; Liu, Z. Synthesis of Nitrogen-Doped Graphene Using Embedded Carbon and Nitrogen Sources. Adv. Mater. 2011, 23, 1020-1024. [CrossRef] [PubMed]

153. Li, X.; Wang, H.; Robinson, J.T.; Sanchez, H.; Diankov, G.; Dai, H. Simultaneous Nitrogen Doping and Reduction of Graphene Oxide. J. Am. Chem. Soc. 2009, 131, 15939-15944. [CrossRef]

154. Sheng, Z.-H.; Shao, L.; Chen, J.-J.; Bao, W.-J.; Wang, F.-B.; Xia, X.-H. Catalyst-Free Synthesis of Nitrogen-Doped Graphene via Thermal Annealing Graphite Oxide with Melamine and Its Excellent Electrocatalysis. ACS Nano 2011, 5, 4350-4358. [CrossRef]

155. Yang, S.-Y.; Chang, K.-H.; Huang, Y.-L.; Lee, Y.-F.; Tien, H.-W.; Li, S.-M.; Liu, C.-H.; Ma, C.-C.M.; Hu, C.-C. A powerful approach to fabricate nitrogen-doped graphene sheets with high specific surface area. Electrochem. Commun. 2012, 14, 39-42. [CrossRef]

156. Mayavan, S.; Sim, J.-B.; Choi, S.-M. Easy synthesis of nitrogen-doped graphene-silver nanoparticle hybrids by thermal treatment of graphite oxide with glycine and silver nitrate. Carbon 2012, 50, 5148-5155. [CrossRef]

157. She, Y.; Chen, J.; Zhang, C.; Lu, Z.; Ni, M.; Sit, P.H.-L.; Leung, M.K.H. Nitrogen-doped graphene derived from ionic liquid as metal-free catalyst for oxygen reduction reaction and its mechanisms. Appl. Energy 2018, 225, 513-521. [CrossRef]

158. Panchakarla, L.S.; Subrahmanyam, K.S.; Saha, S.K.; Govindaraj, A.; Krishnamurthy, H.R.; Waghmare, U.V.; Rao, C.N.R. Synthesis, Structure, and Properties of Boron- and Nitrogen-Doped Graphene. Adv. Mater. 2009, 21, 4726-4730. [CrossRef]

159. Hulicova, D.; Yamashita, J.; Soneda, Y.; Hatori, A.H.; Kodama, M. Supercapacitors Prepared from Melamine-Based Carbon. Chem. Mater. 2005, 17, 1241-1247. [CrossRef]

160. Yang, H.B.; Miao, J.; Hung, S.-F.; Chen, J.; Tao, H.B.; Wang, X.; Zhang, L.; Chen, R.; Gao, J.; Chen, H.M.; et al. Identification of catalytic sites for oxygen reduction and oxygen evolution in N-doped graphene materials: Development of highly efficient metal-free bifunctional electrocatalyst. Sci. Adv. 2016, 2, e1501122. [CrossRef]

161. Liu, Y.; Zhao, J.; Cai, Q. Pyrrolic-nitrogen doped graphene: A metal-free electrocatalyst with high efficiency and selectivity for the reduction of carbon dioxide to formic acid: A computational study. Phys. Chem. Chem. Phys. 2016, 18, 5491-5498. [CrossRef]

162. Ju, M.J.; Kim, J.C.; Choi, H.-J.; Choi, I.T.; Kim, S.G.; Lim, K.; Ko, J.; Lee, J.-J.; Jeon, I.-Y.; Baek, J.-B.; et al. N-Doped Graphene Nanoplatelets as Superior Metal-Free Counter Electrodes for Organic Dye-Sensitized Solar Cells. ACS Nano 2013, 7, 5243-5250. [CrossRef] [PubMed]

163. Rahsepar, M.; Nobakht, M.R.; Kim, H.; Pakshir, M. Facile enhancement of the active catalytic sites of N-doped graphene as a high performance metal-free electrocatalyst for oxygen reduction reaction. Appl. Surf. Sci. 2018, 447, 182-190. [CrossRef]

164. Maouche, C.; Zhou, Y.; Li, B.; Cheng, C.; Wu, Y.; Li, J.; Gao, S.; Yang, J. Thermal treated three-dimensional N-doped graphene as efficient metal free-catalyst for oxygen reduction reaction. J. Electroanal. Chem. 2019, 853, 113536. [CrossRef]

165. Kumar, M.P.; Raju, M.M.; Arunchander, A.; Selvaraj, S.; Kalita, G.; Narayanan, T.N.; Sahu, A.K.; Pattanayak, D.K. Nitrogen Doped Graphene as Metal Free Electrocatalyst for Efficient Oxygen Reduction Reaction in Alkaline Media and Its Application in Anion Exchange Membrane Fuel Cells. J. Electrochem. Soc. 2016, 163, F848. [CrossRef]

166. Hu, K.; Xiao, Z.; Cheng, Y.; Yan, D.; Chen, R.; Huo, J.; Wang, S. Iron phosphide/N, P-doped carbon nanosheets as highly efficient electrocatalysts for oxygen reduction reaction over the whole $\mathrm{pH}$ range. Electrochim. Acta 2017, 254, 280-286. [CrossRef]

167. Yang, Z.; Yao, Z.; Li, G.; Fang, G.; Nie, H.; Liu, Z.; Zhou, X.; Chen, X.; Huang, S. Sulfur-Doped Graphene as an Efficient Metal-free Cathode Catalyst for Oxygen Reduction. ACS Nano 2012, 6, 205-211. [CrossRef]

168. Zhao, Y.; Yang, L.; Chen, S.; Wang, X.; Ma, Y.; Wu, Q.; Jiang, Y.; Qian, W.; Hu, Z. Can Boron and Nitrogen Co-doping Improve Oxygen Reduction Reaction Activity of Carbon Nanotubes? J. Am. Chem. Soc. 2013, 135, 1201-1204. [CrossRef]

169. Sun, X.; Song, P.; Zhang, Y.; Liu, C.; Xu, W.; Xing, W. A Class of High Performance Metal-Free Oxygen Reduction Electrocatalysts based on Cheap Carbon Blacks. Sci. Rep. 2013, 3, 2505. [CrossRef]

170. Liu, Z.; Nie, H.; Yang, Z.; Zhang, J.; Jin, Z.; Lu, Y.; Xiao, Z.; Huang, S. Sulfur-nitrogen co-doped three-dimensional carbon foams with hierarchical pore structures as efficient metal-free electrocatalysts for oxygen reduction reactions. Nanoscale 2013, 5, 3283-3288. [CrossRef]

171. Li, Y.; Zhang, H.; Wang, Y.; Liu, P.; Yang, H.; Yao, X.; Wang, D.; Tang, Z.; Zhao, H. A self-sponsored doping approach for controllable synthesis of $\mathrm{S}$ and $\mathrm{N}$ co-doped trimodal-porous structured graphitic carbon electrocatalysts. Energy Environ. Sci. 2014, 7, 3720-3726. [CrossRef] 
172. Liang, J.; Jiao, Y.; Jaroniec, M.; Qiao, S.Z. Sulfur and Nitrogen Dual-Doped Mesoporous Graphene Electrocatalyst for Oxygen Reduction with Synergistically Enhanced Performance. Angew. Chem. Int. Ed. 2012, 51, 11496-11500. [CrossRef] [PubMed]

173. Wohlgemuth, S.-A.; White, R.J.; Willinger, M.-G.; Titirici, M.-M.; Antonietti, M. A one-pot hydrothermal synthesis of sulfur and nitrogen doped carbon aerogels with enhanced electrocatalytic activity in the oxygen reduction reaction. Green Chem. 2012, 14, 1515-1523. [CrossRef]

174. Wohlgemuth, S.-A.; Vilela, F.; Titirici, M.-M.; Antonietti, M. A one-pot hydrothermal synthesis of tunable dual heteroatom-doped carbon microspheres. Green Chem. 2012, 14, 741-749. [CrossRef]

175. Wu, Y.; Fang, S.; Jiang, Y.; Holze, R. Effects of doped sulfur on electrochemical performance of carbon anode. J. Power Sources 2002, 108, 245-249. [CrossRef]

176. Choi, C.H.; Park, S.H.; Woo, S.I. Heteroatom doped carbons prepared by the pyrolysis of bio-derived amino acids as highly active catalysts for oxygen electro-reduction reactions. Green Chem. 2011, 13, 406-412. [CrossRef]

177. Inamdar, S.N.; Haram, S.K. Synthesis and Characterization of Uncapped $\gamma-\mathrm{Fe}_{2} \mathrm{O}_{3}$ Nanoparticles Prepared by Flame Pyrolysis of Ferrocene in Ethanol. J. Nanosci. Nanotechnol. 2006, 6, 2155-2158. [CrossRef] [PubMed]

178. Inamdar, S.; Choi, H.-S.; Wang, P.; Song, M.Y.; Yu, J.-S. Sulfur-containing carbon by flame synthesis as efficient metal-free electrocatalyst for oxygen reduction reaction. Electrochem. Commun. 2013, 30, 9-12. [CrossRef]

179. Park, J.-E.; Jang, Y.J.; Kim, Y.J.; Song, M.-S.; Yoon, S.; Kim, D.H.; Kim, S.-J. Sulfur-doped graphene as a potential alternative metal-free electrocatalyst and Pt-catalyst supporting material for oxygen reduction reaction. Phys. Chem. Chem. Phys. 2014, 16, 103-109. [CrossRef]

180. Zhang, H.; Niu, Y.; Hu, W. Nitrogen/sulfur-doping of graphene with cysteine as a heteroatom source for oxygen reduction electrocatalysis. J. Colloid Interface Sci. 2017, 505, 32-37. [CrossRef]

181. Zhao, H.; Zhu, Y.-P.; Ge, L.; Yuan, Z.-Y. Nitrogen and sulfur co-doped mesoporous hollow carbon microspheres for highly efficient oxygen reduction electrocatalysts. Int. J. Hydrog. Energy 2017, 42, 19010-19018. [CrossRef]

182. Wang, Y.; Zhu, M.; Li, Y.; Zhang, M.; Xue, X.; Shi, Y.; Dai, B.; Guo, X.; Yu, F. Heteroatom-doped porous carbon from methyl orange dye wastewater for oxygen reduction. Green Energy Environ. 2018, 3, 172-178. [CrossRef]

183. Tumwesigye, K.S.; Oliveira, J.C.; Sousa-Gallagher, M.J. New sustainable approach to reduce cassava borne environmental waste and develop biodegradable materials for food packaging applications. Food Packag. Shelf Life 2016, 7, 8-19. [CrossRef]

184. Mena-Durán, C.J.; Alonso-Lemus, I.L.; Quintana, P.; Barbosa, R.; Ordoñez, L.C.; Escobar, B. Preparation of metal-free electrocatalysts from cassava residues for the oxygen reduction reaction: A sulfur functionalization approach. Int. J. Hydrog. Energy 2018, 43, 3172-3179. [CrossRef]

185. Yang, D.-S.; Bhattacharjya, D.; Inamdar, S.; Park, J.; Yu, J.-S. Phosphorus-Doped Ordered Mesoporous Carbons with Different Lengths as Efficient Metal-Free Electrocatalysts for Oxygen Reduction Reaction in Alkaline Media. J. Am. Chem. Soc. 2012, 134, 16127-16130. [CrossRef]

186. Prasad, K.S.; Pallela, R.; Kim, D.-M.; Shim, Y.-B. Microwave-Assisted One-Pot Synthesis of Metal-Free Nitrogen and Phosphorus Dual-Doped Nanocarbon for Electrocatalysis and Cell Imaging. Part. Part. Syst. Charact. 2013, 30, 557-564. [CrossRef]

187. Li, R.; Wei, Z.; Gou, X.; Xu, W. Phosphorus-doped graphene nanosheets as efficient metal-free oxygen reduction electrocatalysts RSC Adv. 2013, 3, 9978-9984. [CrossRef]

188. Qiao, X.; Liao, S.; You, C.; Chen, R. Phosphorus and Nitrogen Dual Doped and Simultaneously Reduced Graphene Oxide with High Surface Area as Efficient Metal-Free Electrocatalyst for Oxygen Reduction. Catalysts 2015, 5, 981-991. [CrossRef]

189. Yang, D.-S.; Bhattacharjya, D.; Song, M.Y.; Yu, J.-S. Highly efficient metal-free phosphorus-doped platelet ordered mesoporous carbon for electrocatalytic oxygen reduction. Carbon 2014, 67, 736-743. [CrossRef]

190. Jiang, H.; Zhu, Y.; Feng, Q.; Su, Y.; Yang, X.; Li, C. Nitrogen and Phosphorus Dual-Doped Hierarchical Porous Carbon Foams as Efficient Metal-Free Electrocatalysts for Oxygen Reduction Reactions. Chemistry 2014, 20, 3106-3112. [CrossRef]

191. Yu, D.; Xue, Y.; Dai, L. Vertically Aligned Carbon Nanotube Arrays Co-doped with Phosphorus and Nitrogen as Efficient Metal-Free Electrocatalysts for Oxygen Reduction. J. Phys. Chem. Lett. 2012, 3, 2863-2870. [CrossRef]

192. Li, Q.; Cao, R.; Cho, J.; Wu, G. Nanocarbon Electrocatalysts for Oxygen Reduction in Alkaline Media for Advanced Energy Conversion and Storage. Adv. Energy Mater. 2014, 4, 1301415. [CrossRef]

193. Liu, X.; Antonietti, M. Moderating Black Powder Chemistry for the Synthesis of Doped and Highly Porous Graphene Nanoplatelets and Their Use in Electrocatalysis. Adv. Mater. 2013, 25, 6284-6290. [CrossRef]

194. Yang, L.; Jiang, S.; Zhao, Y.; Zhu, L.; Chen, S.; Wang, X.; Wu, Q.; Ma, J.; Ma, Y.; Hu, Z. Boron-Doped Carbon Nanotubes as Metal-Free Electrocatalysts for the Oxygen Reduction Reaction. Angew. Chem. Int. Ed. 2011, 50, 7132-7135. [CrossRef]

195. Zou, X.; Wang, L.; Yakobson, B.I. Mechanisms of the oxygen reduction reaction on B- and/or N-doped carbon nanomaterials with curvature and edge effects. Nanoscale 2018, 10, 1129-1134. [CrossRef] [PubMed]

196. Sheng, Z.-H.; Gao, H.-L.; Bao, W.-J.; Wang, F.-B.; Xia, X.-H. Synthesis of boron doped graphene for oxygen reduction reaction in fuel cells. J. Mater. Chem. 2012, 22, 390-395. [CrossRef]

197. Liu, Y.; Chen, S.; Quan, X.; Yu, H.; Zhao, H.; Zhang, Y.; Chen, G. Boron and Nitrogen Codoped Nanodiamond as an Efficient Metal-Free Catalyst for Oxygen Reduction Reaction. J. Phys. Chem. C 2013, 117, 14992-14998. [CrossRef]

198. Qian, Y.; Hu, Z.; Ge, X.; Yang, S.; Peng, Y.; Kang, Z.; Liu, Z.; Lee, J.Y.; Zhao, D. A metal-free ORR/OER bifunctional electrocatalyst derived from metal-organic frameworks for rechargeable Zn-Air batteries. Carbon 2017, 111, 641-650. [CrossRef] 
199. Xu, C.; Su, Y.; Liu, D.; He, X. Three-dimensional N,B-doped graphene aerogel as a synergistically enhanced metal-free catalyst for the oxygen reduction reaction. Phys. Chem. Chem. Phys. 2015, 17, 25440-25448. [CrossRef]

200. Zhou, Y.; Sun, Y.; Wang, H.; Zhu, C.; Gao, J.; Wu, D.; Huang, H.; Liu, Y.; Kang, Z. A nitrogen and boron co-doped metal-free carbon electrocatalyst for an efficient oxygen reduction reaction. Inorg. Chem. Front. 2018, 5, 2985-2991. [CrossRef]

201. Wang, Q.; Yan, J.; Fan, Z. Carbon materials for high volumetric performance supercapacitors: Design, progress, challenges and opportunities. Energy Environ. Sci. 2016, 9, 729-762. [CrossRef]

202. Tian, W.; Gao, Q.; Tan, Y.; Yang, K.; Zhu, L.; Yang, C.; Zhang, H. Bio-inspired beehive-like hierarchical nanoporous carbon derived from bamboo-based industrial by-product as a high performance supercapacitor electrode material. J. Mater. Chem. A 2015, 3 , 5656-5664. [CrossRef]

203. Yang, C.-S.; Jang, Y.S.; Jeong, H.K. Bamboo-based activated carbon for supercapacitor applications. Curr. Appl. Phys. 2014, 14, 1616-1620. [CrossRef]

204. Sun, L.; Tian, C.; Li, M.; Meng, X.; Wang, L.; Wang, R.; Yin, J.; Fu, H. From coconut shell to porous graphene-like nanosheets for high-power supercapacitors. J. Mater. Chem. A 2013, 1, 6462-6470. [CrossRef]

205. Mi, J.; Wang, X.-R.; Fan, R.-J.; Qu, W.-H.; Li, W.-C. Coconut-Shell-Based Porous Carbons with a Tunable Micro/Mesopore Ratio for High-Performance Supercapacitors. Energy Fuels 2012, 26, 5321-5329. [CrossRef]

206. Song, K.; Wu, Q.; Zhang, Z.; Ren, S.; Lei, T.; Negulescu, I.I.; Zhang, Q. Porous Carbon Nanofibers from Electrospun Biomass Tar/Polyacrylonitrile/Silver Hybrids as Antimicrobial Materials. ACS Appl. Mater. Interfaces 2015, 7, 15108-15116. [CrossRef]

207. Huang, Y.; Peng, L.; Liu, Y.; Zhao, G.; Chen, J.Y.; Yu, G. Biobased Nano Porous Active Carbon Fibers for High-Performance Supercapacitors. ACS Appl. Mater. Interfaces 2016, 8, 15205-15215. [CrossRef]

208. Balducci, A.; Henderson, W.A.; Mastragostino, M.; Passerini, S.; Simon, P.; Soavi, F. Cycling stability of a hybrid activated carbon/ / poly(3-methylthiophene) supercapacitor with N-butyl-N-methylpyrrolidinium bis(trifluoro methane sulfonyl) imide ionic liquid as electrolyte. Electrochim. Acta 2005, 50, 2233-2237. [CrossRef]

209. Sanchez-Gonzalez, J.; Macías-Garcia, A.; Alexandre-Franco, M.F.; Gómez-Serrano, V. Electrical conductivity of carbon blacks under compression. Carbon 2005, 43, 741-747. [CrossRef]

210. Bang, J.H.; Lee, H.-M.; An, K.-H.; Kim, B.-J. A study on optimal pore development of modified commercial activated carbons for electrode materials of supercapacitors. Appl. Surf. Sci. 2017, 415, 61-66. [CrossRef]

211. Gu, W.; Wei, L.; Yushin, G. Capacitive energy storage. In Energy Storage; World Scientific: Singapore, 2017; pp. 167-214.

212. Dubey, R.; Guruviah, V. Review of carbon-based electrode materials for supercapacitor energy storage. Ionics 2019, 25, 1419-1445. [CrossRef]

213. Gong, K.; Du, F.; Xia, Z.; Durstock, M.; Dai, L. Nitrogen-Doped Carbon Nanotube Arrays with High Electrocatalytic Activity for Oxygen Reduction. Science 2009, 323, 760-764. [CrossRef]

214. Duan, X.; Indrawirawan, S.; Sun, H.; Wang, S. Effects of nitrogen-, boron-, and phosphorus-doping or codoping on metal-free graphene catalysis. Catal. Today 2015, 249, 184-191. [CrossRef]

215. Fu, P.; Zhou, L.; Sun, L.; Huang, B.; Yuan, Y. Nitrogen-doped porous activated carbon derived from cocoon silk as a highly efficient metal-free electrocatalyst for the oxygen reduction reaction. RSC Adv. 2017, 7, 13383-13389. [CrossRef]

216. Liu, Y.; Li, K.; Liu, Y.; Pu, L.; Chen, Z.; Deng, S. The high-performance and mechanism of P-doped activated carbon as a catalyst for air-cathode microbial fuel cells. J. Mater. Chem. A 2015, 3, 21149-21158. [CrossRef]

217. Li, B.; Dai, F.; Xiao, Q.; Yang, L.; Shen, J.; Zhang, C.; Cai, M. Nitrogen-doped activated carbon for a high energy hybrid supercapacitor. Energy Environ. Sci. 2016, 9, 102-106. [CrossRef]

218. Zhang, S.; Shi, X.; Wróbel, R.; Chen, X.; Mijowska, E. Low-cost nitrogen-doped activated carbon prepared by polyethylenimine (PEI) with a convenient method for supercapacitor application. Electrochim. Acta 2019, 294, 183-191. [CrossRef]

219. Zheng, L.; Li, W.B.; Chen, J.L. Nitrogen doped hierarchical activated carbons derived from polyacrylonitrile fibers for $\mathrm{CO}_{2}$ adsorption and supercapacitor electrodes. RSC Adv. 2018, 8, 29767-29774. [CrossRef]

220. Zhao, H.; Sun, C.; Jin, Z.; Wang, D.-W.; Yan, X.; Chen, Z.; Zhu, G.; Yao, X. Carbon for the oxygen reduction reaction: A defect mechanism. J. Mater. Chem. A 2015, 3, 11736-11739. [CrossRef]

221. Yan, X.; Jia, Y.; Odedairo, T.; Zhao, X.; Jin, Z.; Zhu, Z.; Yao, X. Activated carbon becomes active for oxygen reduction and hydrogen evolution reactions. Chem. Commun. 2016, 52, 8156-8159. [CrossRef] 